
Pors Lis la 
Digitized by the Internet Archive in 2011 with funding from University of Toronto 



\section{CONTRIBUTIONS OF THE}

\section{ROYAL ONTARIO MUSEUM OF ZOOLOGY}

No. 1: A FAUNAL SURVEY OF THE LAKE NIPIGON REgion, ONTARIO, by J. R. Dymond, L. L. Snyder, and E. B. S. LOGIER.

(Reprinted from Transactions of the Royal Canadian Institute, Vol. XVI, part, 2, pp. 233-291). 



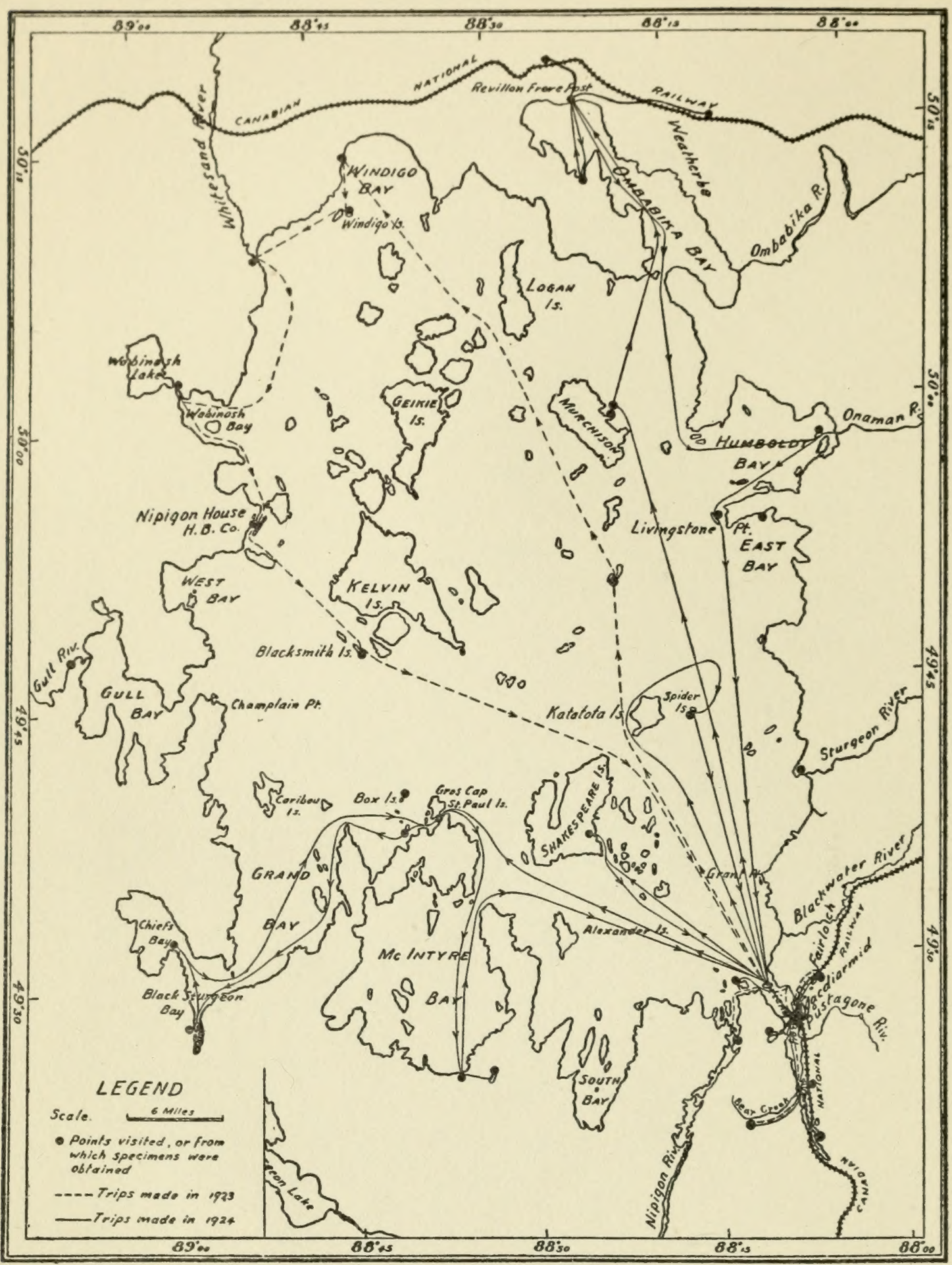

Map of Lake Nipigon

Dymond, Snyder and Logier on A Faunal Investigation of the Lake Nipigon Region 


\title{
A FAUNAL INVESTIGATION OF THE LAKE NIPIGON REGION, ONTARIO $^{1}$
}

\author{
By J. R. Dymond, L. L. Snyder and E. B. S. Logier
}

\section{General Introduction}

Lake Nipigon lies within the Laurentian area of northwestern Ontario, about fifty miles north of Lake Superior. The lake itself occupies the lower portion of a basin-like depression most or all of which at one time constituted a northern bay of glacial Lake Algonquin.

The present water level of the lake is 852 feet above sea level or 250 feet above Lake Superior. It is the largest of the inland lakes of Ontario having an area of 1769 square miles. A characteristic feature is the numerous islands, many of which are quite large. With the exception of the mere rocky projections, these islands are wooded and resemble the elevations of the mainland.

The topography of the surrounding region is much rougher than that of the typical Archaean formation as a result of extensive flows of diabase which occurred at some time in its geological history. The region is characterised by numerous elevations of crystalline rock with intervening valleys occupied by bogs and lakes. These depressions drain from one to another by means of streams usually swift and with numerous falls and rapids in their courses.

The forest of the region is dense and composed principally of mixed stands. Variation in the type occurs somewhat according to the elevation, the high, dry hill-tops frequently supporting stunted and scattered jack pine while down the slopes grow aspen poplar, balsam fir, white spruce, paper birch, and balsam poplar. In some places the deciduous trees predominate over the coniferous and in other places this condition is reversed. Black spruce is sometimes found on high ground but it is generally confined to the lower, boggy areas. White cedar grows in some of the moist situations especially along stream courses and an occasional black ash is also to be found there. Tamarack occurs in many of the bogs but the trees are for the most part quite small. Mountain ash, white pine and red pine are rather rare but may occasionally be found. The principal shrubby trees of the forest are speckled alder

${ }^{1}$ Contribution from the Royal Ontario Museum of Zoology, Toronto. 
and mountain maple, the former bordering many of the lakes or covering the bottoms of damp basins between elevations, and the latter generally distributed over the floor of the mixed forest.

The climate of the Lake Nipigon region may be judged from the following data supplied by the Meteorological Service of Canada. In January the mean daily maximum varies from $8^{\circ}$ to $12^{\circ} \mathrm{F}$., and the mean daily minimum from $-10^{\circ}$ to $-14^{\circ} \mathrm{F}$. In July the lake is crossed by the isotherm of $74^{\circ}$ mean maximum temperature while the isotherm of $32^{\circ} \mathrm{F}$. mean annual temperature touches the north end of the lake. The precipitation is from 22 to 25 inches annually. The frost-free period varies in length from sixty to eighty days. Ice usually leaves the lake between the first and fifteenth of May and usually does not form sufficiently to close navigation until late in December. Surface temperatures (centigrade) of the water of the open lake during the summer months are recorded by Clemens $(1923,1924 a, 1924 b)$ as follows:

Date June 17 July 9 Aug. 29 June 27 July 29 Aug. 17 July 11 Aug. 15 Sept. 14 $\begin{array}{lllllllll}\text { Temp. } 12.5 & 22.0 & 17.1 & 10.3 & 18.2 & 17.6 & 15.3 & 14.5 & 11.3^{2}\end{array}$

The Canadian National Railway touches the southern end of Lake Nipigon at Macdiarmid and Orient Bay station while the old National Transcontinental Railway (now Canadian National) passes within a few miles of its northern end. The Canadian Pacific Railway comes within thirty-five miles of the south end of the lake at the town of Nipigon.

The region surrounding the lake is included in the Nipigon Forest Reserve and is still in its primitive condition although lumbering rights have recently been issued for certain areas within the reserve. The railways and such settlements as the fishing village of Macdiarmid, the Canadian National Railway's tourist lodge at Orient Bay station, the Hudson Bay Company's Post (Nipigon House) and a few small Indian settlements have not altered the primeval conditions generally.

Since 1917 the lake has been open to commercial fishing and now supports a thriving fishing industry, several steam tugs and gasoline boats being thus engaged. The district has been the centre of a large fur trade since the Hudson Bay Company established its post in 1791 . The Lake Nipigon region is known particularly for its speckled trout

${ }^{2}$ During the end of August and the beginning of September 1923 a number of rather violent storms mixed the waters of the lake so thoroughly as to lower the surface temperature and raise that of the lower depths. 
which here reach a very large size. Sportsmen from all over the continent visit the waters of the Nipigon river to angle for the famous "Nipigon trout".

\section{Previous Work}

While Agassiz did not get nearer than the north shore of Lake Superior, his report (1850) was one of the earliest contributions to our knowledge of the geology, fauna and flora of this general region. Atkinson (1894) published a list of birds observed at Port Arthur and more recently Saunders $(1922 a, 1922 b)$ has recorded observations made at Rossport.

The more immediate vicinity of Lake Nipigon has received rather thorough geological study; Bell, McInnes, Dowling, Parks, Coleman and Wilson have all contributed. The results of these studies have been summarized in Wilson's report (1910). Wilson, in connection with his geological work, published lists of trees, fishes, amphibians, reptiles, birds and mammals. Other studies of the fauna and flora of the immediate vicinity of Lake Nipigon have been made by Miller (1897), Jennings (1915, 1918a, 1918b, 1920), Koelz (1923), Clemens (1923, $1924 a, 1924 b)$, Adamstone (1922, 1924), Walker (1909, 1924), Moore (1924), and Dymond (1926).

\section{Life Zone and Faunal Area}

Although a part of the north shore of Lake Superior was considered by Miller (1897) as lying within the limits of the Hudsonian zone he was not able to ascertain whether this was an isolated area or was continuous with the main transcontinental Hudsonian belt on the north. Recent maps demarcating the life zones of North America do not include the section north of Lake Superior within the Hudsonian zone and quite properly include the Lake Nipigon region within the Algonquin, or forested area of the Canadian zone. Perhaps the best treatment of the faunal areas and life zones of Canada is that of Klugh and McDougall (1924). (The lines limiting the zones and faunal areas on their maps were drawn from meteorological data.) The results of the faunal investigations reported in the accompanying papers are in accord with their views.

The plant life of the region is quite characteristic of the Algonquin area of the Canadian zone and the principal trees of the forest such as balsam fir (Abies balsamea), white spruce (Picea canadensis), black spruce (Picea mariana), paper birch (Betula alba), and aspen poplar (Populus tremuloides) are reliable indicators.

Among the mammal records included in the accompanying report forms of the following species may be considered as characteristic of 
the Algonquin area of the Canadian zone,--moose (Alces americana), Canada lynx (Lynx canadensis), varying hare (Lepus americanus) and woodland jumping mouse (Napaeozapus insignis).

Among the birds the following are some of the more characteristic species of the Algonquin faunal area: white-throated sparrow (Zonotrichia albicollis), magnolia warbler (Dendroica magnolia), Tennessee warbler (Vermivora peregrina), bay-breasted warbler (Dendroica castanea), arctic three-toed woodpecker (Picoides arcticus), Canada jay (Perisoreus canadensis), slate-colored junco (Junco hyemalis) and olivebacked thrush (Hylocichla ustulata swainsoni).

The following insects may be mentioned as characteristic,--butterflies: Eurymus interior Scudd., Oeneis macounii Edw., Oeneis jutta Hbn., Carterocephalus palaemon Pall., and Pamphila manitoba Scudd.; grasshoppers: Circotettix verruculatus Kirby, Podisma glacialis canadensis E. Walk., Melanoplus islandicus Blatchley, and M. dodgei huroni Blatchley; dragonflies: Coenagrion interrogatum Selys, Ophiogomphus colubrinus Selys, O. anomalus Harvey, Aeshna subarctica E. Walk., A. interrupta interrupta E. Walk., Somatochlora walshii Scudd., and S. minor Calvert.

\section{Acknowledgements}

During the prosecution of the work reported herein valuable assistance was received from the staff of the Fisheries Research Laboratory, Department of Biology, University of Toronto who were engaged in fisheries studies on the lake during the summer 1921 to 1924 . Appreciation should also be expressed to numerous residents of the area who contributed in many ways to our faunal studies and whose courtesy and consideration made our stay a pleasant one.

$$
\text { J. R. D. L. L. S. }
$$

\section{Literature Cited}

Adamstone, F. B. 1922. Myxomycetes of the Lake Nipigon district. Can. Field-Naturalist, 36: 129-131.

Adamstone, F. B. 1924. The distribution and economic importance of the bottom fauna of Lake Nipigon. Univ. of Toronto Studies: Biol. Series, Pub. Ont. Fisheries Research Lab., No. 24.

Agassiz, L. 1850. Lake Superior, its physical character, vegetation and animals (with narrative by J. E. Cabot), Boston.

Atkinson, G. E. 1894. A summer's collecting and observations at Port Arthur, Ontario. Biol. Rev. Ont., 1: 94-101.

Clemens, W. A. 1923. The limnology of Lake Nipigon. Univ. of Toronto Studies: Biol. Series, Pub. Ont. Fisheries Research Lab., No. 11. 
Clemens, W. A. 1924a. The limnology of Lake Nipigon in 1922. Univ. of Toronto Studies: Biol. Series, Pub. Ont. Fisheries Research Lab., No. 17.

Clemens, W. A. 1924b. The limnology of Lake Nipigon in 1923. Univ. of Toronto Studies: Biol. Series, Pub. Ont. Fisheries Research Lab., No. 22.

Dymond, J. R. 1926. The fishes of Lake Nipigon. Univ. of Toronto Studies: Biol. Series, Pub. Ont. Fisheries Research Lab., No. 27. Jennings, O. E. 1915. Notes on the pteridophytes of northwestern Ontario. Am. Fern Journ., 5: 33-39.

Jennings, O. E. 1918a. An annotated list of the pteridophytes of northwestern Ontario. Am. Fern Journ., 8: 38-50 and 76-88.

Jennings, O. E. 1918b. Notes on the mosses of northwestern Ontario. The Bryologist, 21: 69-76.

Jennings, O. E. 1920. New or noteworthy plants from northwestern Ontario. Journ. Wash. Acad. of Science, 10:453-460.

Klugh, A. B. and McDougall, E. G. 1924. The faunal areas of Canada. Handbook of Canada, pp. 195-206. University of Toronto Press.

Koelz, W. 1923. Some recent records from the Lake Superior region, Ontario. Can. Field-Naturalist, 37: 118.

Miller, G. S. Jr. 1897. Notes on the mammals of Ontario. Proc. Bost. Soc. Nat. Hist., 28: 1-44.

Moore, J. P. 1924. The leeches (Hirudinea) of Lake Nipigon. Univ. of Toronto Studies: Biol. Series, Pub. Ont. Fisheries Research Lab., No. 23.

Saunders, W. E. 1922a. Occurrence of the red-throated loon at Rossport, Ontario. Can. Field- Naturalist, 36: 137.

Saunders, W. E. 1922b. Occurrence of the rock vole at Rossport, Ontario. Can. Field-Naturalist, 36: 138.

Walker, E. M. 1909. On the Orthoptera of northern Ontario. Can. Ent., 42: 137-144; 173-178; 205-212.

Walker, E. M. 1924. The Odonata of the Thunder Bay District, Ontario. Can. Ent., 56: 182-189.

Wilson, A. W. G. 1910. Geology of the Nipigon basin, Ontario. Memoir No. 1, Dept. Mines, Geol. Survey Branch, Ottawa. 

Reprinted from Transactions Royal Canadian Institute, Vol. XVI, Part 2, 1928.

\title{
THE MAMMALS OF THE LAKE NIPIGON REGION
}

\author{
By J. R. DyMond
}

The following paper is the result of observations and collections made during four summers (1921-24) which the writer spent on Lake Nipigon in connection with the work of the Fisheries Research Laboratory of the Department of Biology, University of Toronto. This work was done incidentally whenever time could be spared from the work of the Fisheries Laboratory and is necessarily less complete than could have been desired.

Valuable assistance in the accumulation of data was received from Mr. Duncan Bell of McIntyre bay, Lake Nipigon and Mr. P. McGuire, Factor of the Hudson's Bay Company's post at Nipigon House. For this assistance I wish to express my appreciation and thanks.

Specimens of the following were submitted to the Bureau of Biological Survey, Washington, D.C.: Sorex c. cinereus, Sorex arcticus, Microsorex hoyi intervectus, Blarina brevicauda talpoides, Eutamias minimus jacksoni, Tamias striatus griseus, Peromyscus maniculatus maniculatus, Synaptomys cooperi fatuus, Evotomys g. gapperi, Microtus pennsylvanicus fontigenus. For the examination and determination of this material I am very much indebted. My thanks are also due Dr. Glover M. Allen of the Museum of Comparative Zoology for the determination of the bat Myotis l. lucifugus.

The measurements given for some of the species are in millimetres. Unless otherwise stated, L. is the total length in millimetres from the snout to the end of the tail vertebrae, $\mathrm{T}$. is the length in millimetres of the tail and H. F. the length in millimetres of the hind foot from the heel to the end of the longest claw.

Condylura cristata (LINN.). STAR-NOSED MOLE.-Only two specimens were taken, the first by Dr. Walter Koelz who spent two weeks on Lake Nipigon in July 1922. The other was trapped in a store at Gull Bay village on August 7, 1923. Average of two specimens: L.,

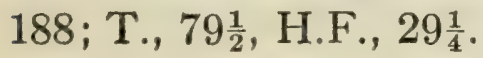

Sorex cinereus cinereus KERR. MASKED SHREW.-This is the species which before Jackson's recent studies of the shrews (1925a) has been known as Sorex personatus Eight specimens taken, average measurements of six: L. 94 ; T., 39; H.F., 12. Specimens were taken 
in damp woods, among rocks in a small clearing and among alders at the water's edge. The latter situation appeared to be a favourite one for this species.

Sorex arcticus KERR. (S. richardsonii Bachman. See Jackson loc. cit.). RICHARDSON'S SHREW.-Only two specimens taken. Aver-

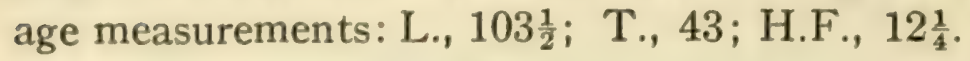

Microsorex hoyi intervectus JACKSON. HOY'S SHREW.-A specimen of this small shrew was taken at Macdiarmid by Mr. L. L. Snyder on June 27, 1923. This subspecies has recently been described by Jackson (1925b).

Blarina brevicauda talpoides (GAPPER). MOLE SHREW.-The mole shrew was very common being exceeded in point of numbers only by the white-footed mouse among the small mammals. It is perhaps most numerous in damp, cool woods but several specimens were also taken in drier situations and in clearings. Five were taken in two successive nights in August 1924 around a small water hole in the woods about 50 yards from my tent. Average measurements of 23 specimens:

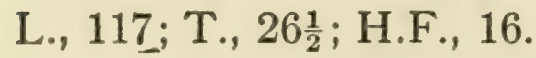

\section{Myotis lucifugus lucifugus (LE CONTE). LITTLE BROWN} BAT.-This was the only species of bat of which we secured specimens. Bats were rarely seen on the wing and our only specimens were found by day in lumber piles.

Euarctos americanus americanus (PALlAs). BLACK BEAR.Fairly common. In 1921 they were far more common than during any of the three succeeding years. During the autumn of that year more than a dozen were shot or trapped in the immediate neighbourhood of Macdiarmid. A favourite feeding ground is across Orient bay from the village where the offal resulting from the dressing of fish shipped to market together with the useless species taken in the fishermen's nets are thrown on the rocks to decay. No cinnamon specimens have been reported.

Procyon lotor lotor (LINN.). RACCOON.-Miller (1897) was told by Mr. William McKirdy of Nipigon that a few years previously a raccoon was killed by some Indians near Lake Nipigon and brought to the Hudson Bay Company's post. The Port Arthur News-Chronicle of November 8, 1921 reported that a farmer living in the vicinity of Kakabeka Falls (west of Fort William) had killed a raccoon in that district a day or two previously. This mammal, however, is not normally found in this part of Ontario. 
Martes americana americana (TURTON). MARTEN.-Quite a number of martens are still taken in the Nipigon region but they are much less common than formerly. According to the Indians, a trapper sometimes got as many as 15 or 20 from one round of the traps whereas now he is lucky to get that number in a season.

A specimen taken December 15, 1921 near McIntyre bay was measured by Mr. Bell; L., 592; T., 188; H.F., 102. They vary much in colour from dark brown to yellowish.

Martes pennanti pennanti (ERXLEBEN). FISHER.-The fisher is also much less common than formerly but is still one of the valuable fur mammals of the district. A specimen taken on Gros Cap. Nov. 19, 1921 was measured by Mr. Bell; L., 864; T., 334; H.F., 125. A fire ranger reported seeing a female fisher with three young during the summer of 1922. Another ranger was said to have seen five young with an adult and thought the latter a more usual number.

Mustela cicognanii cicognanii Bonaparte. SHORT-TAILED WEASEL. - The weasel was common throughout the region. A series secured for us during the winter of 1921-22 by Mr. Duncan Bell gave the following measurements: 4 males, L., 293; T., 81; H.F., 38; 2 females, L., 228; T., 55; H.F., 28.

A specimen taken on Nov. 10, 1921 still had considerable brown showing down the centre of its back, top of head and in the tail.

Mustela vison lacustris (Preble). MINK.-Common. A specimen (male) secured for us by Mr. Duncan Bell measured: L., 594; T., 178; H.F., 67 and weighed 2 pounds 14 ounces.

Gulo luscus (LINN.). WOLVERENE.-The wolverene is not normally found in this district. One skin was brought into the Hudson Bay post at Nipigon House a few years ago but it is not known how close to Lake Nipigon it was taken.

Lutra canadensis canadensis (Schreber). OTTER.-A few otters are still taken around Lake Nipigon. They are said to have been common formerly.

Mephitis mephitis (Schreber). SKUNK.-Skunks were rather rare. Mr. and Mrs. Snyder saw one at the Revillon Frères post on Ombabika bay, in June 1924.

Vulpes fulva (Desmarest). FOX.-Foxes appear to fluctuate in numbers with the hares. During 1921 and 1922 when the latter were so scarce very few foxes were taken, but previous to the last dying off of the hares they were more common. 
Canis lycaon Schreber. GRAY or TIMBER WOLF.-The gray or timber wolf was said to be common and quite destructive to moose, deer and beaver. During the summer of $1920 \mathrm{Mr}$. A. Ticknor killed two which he overtook while they were swimming in the lake near the island of Katatota. Mr. McGuire says they will swim after moose and kill them in the water.

Besides the timber wolf there is a smaller form known as the brush wolf and some of the people of the district are of the opinion that there is still another small wolf distinct from the brush wolf which they believe to be the coyote. We saw only one wolf. This we took to be a young one. Its total length was 37 inches, tail 12 inches.

Lynx canadensis canadensis KerR. CANADA LYNX.- The Canada lynx was very scarce during the winter of 1921-22 presumably due to the scarcity of hares. It is usually quite common.

Marmota monax canadensis (ERXLEBEN). WOODCHUCK.The woodchuck was rare except in clearings and along the railroad tracks. Individuals were seen on several occasions along the C.N.R. tracks in the vicinity of Macdiarmid, and at the Revillon Frères abandoned post on Ombabika bay, but Mr. Duncan Bell states that he has never seen one at McIntyre bay.

Only one adult and two immature specimens taken. The adult, a female, measured: L., 498; T., 132; H.F., 71.

Eutamias minimus jacksoni Howell. WESTERN CHIPMUNK.-This form of the western chipmunk, recently described by Howell (1925) ranges through northern Wisconsin, Minnesota and Michigan and eastward along the north shore of Lake Superior as far as Nipigon where it is said to intergrade with Eutamias m. borealis. Lake Nipigon is believed to be very near the eastern boundary of its range.

This chipmunk was observed most frequently about clearings,around coal piles at Macdiarmid, near an old board walk at the abandoned Revillon Frêres fur post at Ombabika bay, near the Mission house at McIntyre bay and in clearings around our tents. A specimen taken Aug. 19, 1921 had 438 seeds of lambs quarters (Chenopodium album) in its cheek pouches. Average of eleven specimens: L., 199; T., 94; H.F., 31.

Tamias striatus griseus MEARns. EASTERN CHIPMUNK.The eastern chipmunk was common. Average of eleven specimens: L., 258; T., 105; H.F., 37. 
Sciurus hudsonicus hudsonicus (ERXLEBEN). RED SQUIRREL. - The red squirrel was not particularly abundant during the summers we spent on Lake Nipigon. Average measurements of seven specimens: L., 295; T., 117; H.F., 45.

Glaucomys sabrinus sabrinus (SHAw). NORTHERN FLYING SQUIRREL.-No flying squirrels were seen during our four summers on Lake Nipigon but four were collected for us by Mr. Duncan Bell during the winter of 1921-22. They are said to be quite common and to be frequently taken in traps set for fur-bearing mammals during the winter. Average measurements of four specimens: L., 313; T., 138; H.F., 40.

Castor canadensis canadensis KUHL. BEAVER.-The beaver is still quite common especially back some distance from the lake and forms an important item in the fur production of the district. No specimens were taken.

Peromyscus maniculatus maniculatus (WAGNer). WHITEFOOTED MOUSE.-White-footed mice were very common. During the summer of 1921 they were excessively abundant, entering stores and dwellings and swarming almost everywhere in the bush. Many were caught in our laboratory above the fish-packing plant. One evening four were taken in less than half an hour in two traps placed on the laboratory table not four feet from where one of the party was sitting and while half a dozen persons sat chatting within a few feet of the table. Out of doors they were taken in the deep bush, in dry clearings, in quaking bogs and by the water's edge. They became active at dusk but one was taken in a trap between 7 a.m. and 1 p.m.

During the early part of the following summer the mice were very scarce, none being taken until after July 1 , although we had placed out more than a dozen traps on several occasions during the preceding month. They became more common later but could always be described as scarce throughout the entire season. During 1923 and 1924 they were more numerous but never approached their abundance during 1921 .

It is believed that other species of small rodents suffered a reduction in numbers at the same time, for meadow mice, red-backed voles and mole shrews were also noticeably scarce during the early part of the summer of 1922 . That the same condition prevailed over a much wider area is suggested by the migration of arctic foxes into the southern part of the Labrador peninsula during April and May 1922. According to Lewis (1923) thousands of Arctic foxes were trapped in southern Labrador before June 1 of that year during what he describes as "A notable in- 
vasion of Arctic foxes". Cabot (1920?) has drawn attention to the periodic fluctuation in the numbers of mice in Labrador and its profound influence on the numbers and distribution of the predaceous birds and mammals of the region. What the species is or whether more than one species is involved is not indicated, except that he described "the mouse of the barrens" as "rather square built, about the size of a common field mouse, with shortish, stumpy tail". This makes it evident, however, that it is not the white-footed mouse that is concerned.

May it not be that the white-footed mouse plays a similar rôle in the northern coniferous forests of Canada to that played in the more northerly regions of Europe and America by the lemmings and voles? (see Elton 1924). Seton (1918) has expressed his view as to the importance of mice in these words: "What moss is to the reindeer, what grass is to the cattle, the mouse millions of the north are to all the northern carnivores from Bear to Blarina. When we shall have fully worked out the life-history of each of these species, I believe we shall learn that the whole of that vast beautiful, important, and specialized production that we call the carnivora rests on a broad simple basis of muridae that in turn rests on the grass, that rests on the earth. We shall for each of these flesh-eaters write, 'it sometimes eats this and sometimes eats that, but by far the greatest bulk of its food is mice.'"

Beyond the fact that the black bear was so abundant during 1921, we made no observations that seem to suggest a correlation between the abundance of mice and that of other creatures. The problem, of course, is complicated by the fluctuation in the number of hares which in this case were scarce when the mice were most numerous.

Average of 41 specimens, a number of which, however, were not fully

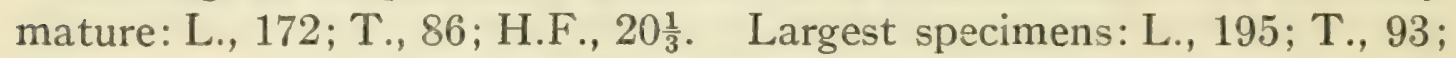
H.F., 21. Eight of the forty-one specimens were $180 \mathrm{~mm}$. or more in total length. It may be of some significance that the specimens taken in 1921 when they were so numerous, averaged smaller than those taken in 1924. Of twenty-one specimens measured in 1921, the average measurements were: L., 167; T., 85; H.F., 201. Only two of these were of $180 \mathrm{~mm}$. or over in total length and one of these came from Shakespeare Island where the population may not have been so dense. Of this, however, we have no data. Of ten specimens taken in 1924 the average measurements were: L., $175 ;$ T., 85 ; H.F., $20 \frac{1}{4}$ and four of the ten were $180 \mathrm{~mm}$. or more in length.

Synaptomys cooperi fatuus BANGs. LEMMING MOUSE.Three specimens were taken by Dr. Koelz while he was on Lake Nipigon in July 1922. One specimen, which he very kindly gave to our museum,

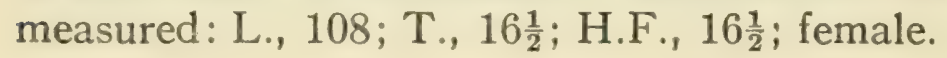


Evotomys gapperi gapperi (VIGoRs). RED-BACKED VOLE.The red-backed vole was not nearly so common, at least so far as the results of our trapping indicate, as the white-footed mouse or the meadow mouse. Most of our specimens were taken during the summer of 1921 when the white-footed mice were also so much more numerous. Average

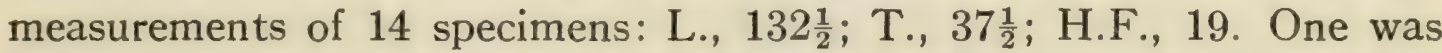
taken in a fire rangers' cabin which we occupied for two nights while camped on Humboldt bay in June 1924. Most of the others were taken in damp, cool woods although a few were trapped in higher, drier situations.

Microtus pennsylvanicus fontigenus (BANGS). MEADOW VOLE.-The meadow vole was fairly common in the clearing around Macdiarmid, especially along a little brook which flows through the southern edge of the village. Average measurements of 22 specimens: L., 147; T., 39; H.F., 20. The largest specimen measured $164 \mathrm{~mm}$, and six of the twenty-two were $160 \mathrm{~mm}$. or over in total length. One specimen was identified by Dr. Hartley H. T. Jackson as "Microtus p. fontigenus approaching "pennsylvanicus".

Ondatra zibethica zibethica (LINN.). MUSKRAT.-The muskrat is comparatively scarce around Lake Nipigon, no doubt due to the small area of marshy land about the lake. Our only specimen was caught in the trap net set for minnows in a small brook flowing through the southern edge of the village of Macdiarmid. It had drowned before the net was lifted. L., 505; T., 238; H.F., 76.

Mus musculus musculus LINN. HOUSE MOUSE.-No specimens were taken during 1921, although more trapping was done that season than during any succeeding year. The first specimen was taken June 16, 1922. Several others were trapped during the same season and by 1924 they had become fairly common. Practically all our specimens were trapped out-of-doors but within the village of Macdiarmid.

Zapus hudsonius hudsonius (Zimmerman). JUMPING MOUSE.-This species was not uncommon. A specimen was found on Aug. 5, 1921 in a trap net set for fish in a small stream flowing into South bay. Whether it had entered the net alive and drowned, or floated in when dead is unknown. The species, however, appears to frequent the banks of streams as quite a number of our specimens were secured in such localities. Average of five specimens taken during July and August 1924: L., 214; T., 131; H.F., 30. 
Napæozapus insignis abietorum (PREBLE). WOODLAND JUMPING MOUSE.-The woodland jumping mouse was less common than the preceding species but like it, was commonly taken along streams. On May 26, 1922 a jumping mouse was seen near a small stream flowing into Sturgeon river. On being alarmed, it entered the water and either ran on the bottom or swam upstream a short distance, then took to the shore, and disappeared into a hole. It was seen for only a few seconds and its method of progression upstream was not clearly made out but it was not by the usual long leaps and it was along the course of the stream. This individual was presumed to be of this species on account of its bright tawny colour. Our observations agree with those of Goodwin (1924) that this species is sometimes active during the daytime. On May 29, 1922 another specimen of this species was seen about noon near the landing place at Sturgeon river. Snyder (1924) has described a nest of the jumping mouse and some features of its behaviour observed at Macdiarmid. Average of three specimens: L., 241; T., 155; H.F., 32.

Erethizon dorsatum dorsatum (LINN.). PORCUPINE.-The porcupine was not very abundant around Lake Nipigon. One was seen on July 19, 1922 on the portage between Black Sturgeon bay and Black Sturgeon lake, and another was seen across the bay from Macdiarmid during the same summer.

Lepus americanus americanus ERXLEBEN. VARYING HARE. - The varying hare was abundant in the Lake Nipigon region during the summer of 1924. In 1921 they were quite scarce but it was difficult to determine definitely the year when they had last been wiped out after reaching their periodic maximum of abundance. From enquiries which I made, it seemed probable, however, that it was during the winter of 1918-19 that they had died off.

On the night of June 18, 1924 while sleeping in an abandoned building at the Revillon Frères post on Ombabika bay, we were disturbed by an animal gnawing in the next room. From the vigorous nature of the gnawing we at once decided that a porcupine was at work and as we had secured no specimen of this mammal we proceeded to set some traps. Hardly had we returned to our beds when the trap was sprung and examination showed that we had caught a hare. The trap was reset and before we had fallen asleep a second specimen had been taken. Next day we heard a similar gnawing and were able to approach quite closely to the animal. The boards that were being gnawed were of hard wood and formed part of the floor of what had been a boarding house during railway construction days. The gnawing was not a continuous 
operation, the hare would rasp the edge of the board vigorously for a few seconds and then cease, apparently to rest for it was quite noticeably panting between gnawing operations. Only two adults taken: L., 444; T., 38; H.F., 135.

Odocoileus virginianus borealis (MILlER). WHITE-TAILED DEER.-The white-tailed deer is a comparatively recent addition to the fauna of the region. It is difficult to fix the date when the species reached Lake Nipigon but it came in after the moose, perhaps twentyfive years ago. Shiras (1921) states that this deer was unknown on the north shore (of Lake Superior) when he came to the region in 1870. It is not yet nearly so numerous around Lake Nipigon as the moose but is rapidly increasing in numbers.

Alces americana americana (Clinton). MOOSE.-Moose are now abundant in the Nipigon region although according to the Indians, they were formerly unknown there. This is supported by the statement of Shiras (loc. cit.) who says that when he first visited Lake Superior in 1870 , moose were practically unknown on the southern or northern shores of this lake, and the same was true, he says, of a large area north of Lake Huron. The invasion by the moose of this territory formerly occupied only by the caribou, Shiras attributes to the improvement in the food conditions through the partial clearing of the country by lumbering and forest fires, followed by the second growth of poplar, birch and other trees and the increase of ground vegetation. Although the territory immediately surrounding Lake Nipigon now forms part of the Nipigon Forest Reserve and has never been cut over nor visited by any serious fires for many years, Bell (1870) found evidence in the Nipigon country that the forests had been swept by fires in past times and the Indians told him that these fires of ten originated from lightning. We ourselves saw a tree set afire by lightning on July 14, 1922 on the hills across the bay from Macdiarmid. This fire was put out by the fire rangers. We were told that it was not unusual for lightning to strike trees in that locality and it was popularly believed that this was due to the presence of iron-bearing rocks. Whatever has been the cause of the migration of the moose into the region, it is evident that they have found conditions here suitable, for they are now very abundant. Mr. Dan Kerr, a fire ranger stationed at a lookout tower near Macdiarmid has seen eleven moose feeding at one time in the little lake at the foot of the hill on which the lookout tower was situated.

Bell (1897) believes that the moose migrates slowly from one large area to another through periods extending over many years and states that in the Gaspe Peninsula the last interval between its leaving and 
again returning to the same district was upward of half a century and in the region between the upper Great Lakes and James bay the period between his last withdrawal and reappearance has been still longer.

Moose were seen on numerous occasions by members of our party. One or two incidents so observed may be worth recording. On July 10, 1923 L. L. Snyder and the writer observed a cow moose feeding in a small lake on a plateau some distance above the level of Lake Nipigon. We had approached the lake noiselessly so as not to scare any ducks which may have been present. On reaching the edge of the lake we saw a brown object in the water about thirty-five or forty yards from us. At first glance it was taken for a log but we soon saw that it was the shoulders of a moose. In a few moments she raised her head but soon put it under the water again and resumed her feeding. At times she was completely submerged; at other times only the points of her shoulders were visible above the water. Sometimes the head was kept under water as long as half a minute but usually for only twenty seconds or less. When she raised her head she sometimes chewed for a short time and sometimes resumed her feeding on the bottom as soon as she had taken a breath of air. After feeding for perhaps fifteen or twenty minutes she waded to shore, shook herself, giving the ears two or three extra shakes and then disappeared, but so noiselessly that we could scarcely believe that she had walked into the bush.

On June 2, 1922 while camped on the Gull river about three miles from the lake, when making breakfast about 8 a.m. a young moose appeared on the opposite shore of the river making a sound resembling that of a child crying. After hesitating for a moment it started to swim towards us. When about ten yards from the shore on which we were standing it turned and swam back to the side from which it had come. The Indians at Gull bay village about a mile away told us afterwards that it had been wandering about alone for two weeks. At the time we saw it the Indians suggested that it would be about a month old and it could not have been much older than that for the young are born here towards the end of April or beginning of May. During that spring and the preceding winter large numbers of moose had died in the district. The Indians believed the loss to be due to ticks and we were given a specimen which was said to have been taken from a dead moose. Unfortunately the specimen was lost before it could be identified. It is quite probable that it belonged to the same species (Dermacentor albipictus Packard) that is reported to have been responsible for the death of so many moose in northern Saskatchewan in the spring of 1916 (Report of the Chief Game Guardian, 1916. Department of Agriculture, Regina, Sask.). 
Rangifer caribou (GMELIN). WOODLAND CARIBOU.-The caribou was formerly the only deer found in the district but has become uncommon especially since the construction of the National Transcontinental Railway across the north end of the lake between 1908 and 1912. Mr. T. U. Fairlie of the Engineering Department of the HydroElectric Power Commission, who was engaged on preliminary location work in connection with the building of the railway, in a letter to the writer states "I was in the district to the north and east of Lake Nipigon in 1904 and 1905 and saw a considerable number of moose, which occasionally travelled in pairs. I saw no red deer for two years, but occasionally saw caribou and on only one occasion on a small muskeg lake about a mile east of Kowcash lake, I saw a herd in January 1905 of 28 caribou. This was the largest herd I saw. We saw evidences of herds at different points, but failed to see the animals".

Fresh tracks were seen in the sand on the beach of Russell Island, Lake Nipigon on July 27, 1922; Aug. 20, 1923 and June 30, 1924, and W. J. K. Harkness and C. S. Hanes saw a male on the Kabitotikwia river on July 24,1924 . Quite a number summer in out of the way places throughout the district.

\section{Literature Cited}

Bell, Robert 1870. On the Nipigon territory. Can. Naturalist, N.S., 5: 120 .

Bell, Robert 1898. On the occurrence of mammoth and mastodon remains around Hudson Bay. Migrations of northern mammals. Bull. Geol. Soc. America, 9: 376.

Cabot, William B. 1920? Labrador. Boston: Small, Maynard \& Co.

Elton, C. S. 1924. Periodic fluctuations in the numbers of animals: their causes and effects. British Journal of Experimental Biology, 2: $119-163$.

Goodwin, George G. 1924. Mammals of the Gaspé peninsula, Quebec. Jour. Mammal., 5: 255.

Howell, Arthur H. 1925. Preliminary descriptions of five new chipmunks from North America. Jour. Mammal., 6: 53.

Jackson, Hartley H. T. 1925a. The Sorex arcticus and Sorex cinereus of Kerr. Jour. Mammal., 6, 55-56.

Jackson, Hartley H. T. 1925b. Two new pigmy shrews of the genus Microsorex. Proc. Biol. Soc. Wash., 38: 125-126.

Lewis, Harrison F. 1923. Additional notes on birds of the Labrador peninsula. Auk, 40: 136 .

Miller, Gerritt S. Jr. 1897. Notes on the mammals of Ontario. Proc. Bost. Soc. Nat. Hist., 28: 41. 
Seton, Ernest Thompson 1918. Life histories of northern animals, 2: 918.

Shiras, Geo., 3rd 1921. The wild life of Lake Superior, past and present. Nat. Geog. Mag., 40: 130.

Snyder, L. L. 1924. Some details on the life history and behavior of Napaeozapus insignis abietorum (Preble). Jour. Mammal., 5: 233-237.

Report of the Chief Game Guardian, 1916. Department of Agriculture, Regina, Sask. 


\title{
THE SUMMER BIRDS OF LAKE NIPIGON
}

\author{
By L. L. SNYdeR \\ Introduction And Acknowledgements
}

Although considerable information is extant on the distribution of birds during the breeding season in the vast Province of Ontario, additional data are needed from many localities, especially in Northern Ontario, where little or no work has been done. Lake Nipigon presented a field of this kind. The geology, botany, ichthyology and limnology of the area have been studied more or less extensively but no systematic record of the summer bird life had been made. It seemed particularly desirable to undertake this work before conditions had become changed by deforestation and industry, and consequently the writer spent the months of June and July, 1923, in field collecting. In 1924 the same months and early August were also spent in the region. The following account of the summer birds is based principally on the collection of skins and the field notes made during these two summers.

The grateful acknowledgement of the writer is due the following persons who in various ways have assisted in the work: Mr. J. H. Fleming of Toronto for his advice and for the use of considerable comparative material; Mr. P. A. Taverner of Ottawa who kindly examined specimens referred to him; Dr. Walter Koelz who has communicated notes relative to certain birds observed by him at Lake Nipigon during the summer of $1922 ;$ Mr. J. L. Baillie of the Museum staff who acted as field assistant during the summer of 1924; and the members of the Fisheries Research Laboratory and Museum staff who assisted in many ways.

\section{General Account}

The area with which the present paper is concerned includes the whole of Lake Nipigon and its immediate shores, no excursions penetrating more than five miles inland having been made during field work. This area consists of approximately 2800 square miles.

A headquarters camp was located at Macdiarmid, a fishing village on Pijitawabik bay (known locally as Orient bay) and it was in this region that a more intensive survey was made, especially during the summer of 1923. From this base, trips were made to other points on the lake. On the map on plate $\mathrm{X}$ the points visited are indicated by a black dot 
and in most cases these marks represent the centre of a reconnoitered area.

The collecting of material was carried on selectively, an attempt being made to secure representative skins of each species occurring in the region in summer. In many cases both sexes are represented and in some the nestlings or immatures as well. In some cases, more particularly where subspecific identity was in question, a series of skins was secured. The collection comprises 313 skins representing 92 species and subspecies, a catalogued collection of the stomachs of all the birds collected, a number of internal and external parasites, 11 nests with eggs and a number of identified nests without eggs and seven nestlings in alcohol.

\section{Annotated List}

There are 99 species or subspecies of birds included in the following list, 92 of which are represented in the collection made by this survey. The other records are based on positive field identifications made by us and material secured by Dr. Walter Koelz in 1922 . No reference is made to Wilson's list since it was not confined to summer birds and was admittedly incomplete.

A catalogue of the specimens secured by us included in which all young of the year are indicated by "Juv." ; birds without mature plumage but known to be in the second year are designated as "Im."

The classification used is that of the Third Edition of the American Ornithologists' Union Check List, 1910, and the nomenclature conforms with this edition with such revisions as have been since made in the supplements published in the 'Auk.'

The matter relating to each species has been paragraphed in the following order,-identity, abundance and local distribution, evidence as to whether the species breeds in the locality or not, and general remarks. Where comment is unnecessary or where information is lacking the corresponding sections have been omitted.

Gavia immer. LOON.-In proportion to the extent of apparently favourable habitat, this species was not common. Single individuals or pairs were seen at widely separated points on Lake Nipigon while none was seen on the numerous small inland lakes in the region.

Two partly feathered young in company with an adult were seen off Shakespeare island on Aug. 4, 1924.

Loons were well known to the fishermen, who mildly objected to their presence, principally on the grounds that they entered the poundnets and were difficult to remove. They did some damage to the trapped fish but on account of their scarcity were not a serious menace 
to fishing. The Indians of the region consider loon's flesh to be good when boiled.

$$
\text { б' July 18, 1924. East bay. }
$$

ㅇ July 26, 1924. East bay.

Larus argentatus. HERRING GULL.-These birds were commonly observed when we were making a lake trip and numbers continually followed the fishing tugs. From forty to seventy-five individuals could be noted about Orient bay on the days when the fishing tugs returned to Macdiarmid. These had followed the boats to port and would gorge themselves on the refuse from fish-dressing operations, which was deposited across the bay.

Four breeding colonies were discovered, one on Box island (J. R. Dymond, May 30, 1922); one on a small island at the entrance to McIntyre bay (known to residents as Grand bay); one on a small rock island about one mile off the northeast shore of Murchison island; and one on a rock cliff on the southwest shore of Ombabika bay. The colony off Murchison island was examined on June 18, 1924, and both newly hatched young and eggs were noted in numbers varying from two to three in a nest. This colony comprised approximately twenty-five pairs.

It seems doubtful if the herring gull does much independent fishing on Lake Nipigon, the offal from the fishing industry affording it a constant food supply. On the rock off Murchison island a number of ling (Lota maculosa) were scattered about. These had probably been found dead by the gulls, as numbers of ling taken from the nets and killed by the fishermen are thrown overboard. Individuals appear to forage over the entire lake, thirty-six adults having followed our boat on one occasion for over twenty miles. Although flocks of gulls were carefully examined, argentatus was the only species seen. No brown immatures were noted except late in the season. It would seem, therefore, that Lake Nipigon is primarily a breeding area and not a feeding range for non-breeding birds.

Juv. ? June 22, 1924. Murchison island. 2 ? July 5, $1923 . \quad$ Naonan island.

Phalacrocorax auritus auritus. DOUBLE-CRESTED CORMORANT.-Cormorants were not common on Lake Nipigon and were not noted during the summer of 1923 , although known to the fishermen, who called them "Soldiers", a name derived from their habit of sitting somewhat upright in what would appear to be straight alignment.

On June 18, 1924, a breeding colony of double-crested cormorants, the first to be found in Ontario, was discovered on a small rock island, about sixty feet long and fifty feet wide, off the northeast shore of Murchison island. On the same island nested a number of herring 
gulls. Nineteen cormorants' nests were counted, and all but one were occupied. The nests contained from four to five naked young, or eggs, or both. Those examined were infested with fleas (unidentified), a large number of which were preserved. Individual cormorants were seen at two other places on Lake Nipigon but no other breeding grounds were found.

The species, according to fishermen, is occasionally taken in the pound-nets, but this is rather unusual, as it prefers to feed in deeper water than that in which pound-nets are set.

Juv. ? June 18, 1924. Murchison island, (alcoholic).

\& June 18, 1924. Murchison island.

$\sigma^{7}$ June 18, 1924. Murchison island.

Mergus americanus. MERGANSER.-The status of this species at Lake Nipigon was not satisfactorily worked out. Mergansers were fairly well distributed about the rocky shores of the mainland and islands, but because of the difficulty in approaching them few were collected. Although field identification was seldom certain, it seems that this species occurs on the lake as frequently as the next.

Mergansers breed on the rocky shores of the mainland and of the islands. Broods of mergansers were noticeably smaller than is frequently recorded, six or seven being the largest number noted.

Mergansers were never noted on the inland lakes nor were they characteristic of the shallow bays of Lake Nipigon. Males were rarely seen and then only at considerable distances, usually near islands far out in the lake. They were not well known to the fishermen and although the two species constituted the most common ducks of the more open water and fed upon small fish, they were not looked upon as detrimental to fishing.

\& June 20, 1923. Macdiarmid. Juv. ơ July 4, 1924. Virgin islands. Juv. o July 4, 1924. Virgin islands. Juv. ? July 4, 1924. Virgin islands.

Mergus serrator. RED-BREASTED MERGANSER.-Not sufficient material was collected to estimate the comparative abundance of this species and the preceding, but it seems probable that they occur in about equal numbers. The evidence at hand, however, makes it clear that the breeding ranges of the two species overlap in the Nipigon region.

A well preserved but abandoned nest of a merganser, thought to be of this species, was found on the boulder-strewn shore of a small island near the northeast shore of Ombabika bay. A family consisting of an adult female and five young was seen off the Windigo islands on July 27,1923 , one young being secured. 
Like the preceding species, the red-breasted merganser seems to prefer to feed in the clear, deep water about islands. No males of this species were positively identified in the field during either summer.

Juv. ơ July 27, 1923. Windigo islands.

Anas platyrhynchos. MALLARD.-This species was met with in only three localities, Humboldt bay, Black Sturgeon bay and Chief bay. The area suited to this duck is comparatively small and it was probably never present in great numbers.

A female and two downy young were observed at the mouth of the Onaman river in Humboldt bay on June 29, 1924. Single females were observed at the two other localities mentioned above and it is probable that they were also breeding birds. A single male was seen in Humboldt bay the day previous to our noting the female with young. Since it was seen in the same small bay in which the family was observed, it may have been the male parent of the brood, not yet having disassociated himself from the female.

Unlike the diving ducks the female mallard took wing when approached, leaving the young to escape by concealment in the vegetation bordering the bay.

Juv. ơ June 29, 1924. , Humboldt bay.

Anas rubripes. BLACK DUCK.-From the evidence secured it is doubtful if this species is a regular summer resident of the Lake Nipigon region. The only specimen seen was flushed from a small grassy lake near Macdiarmid on June 17, 1924. Although a number of subsequent visits were made to the same lake it was not seen again.

Glaucionetta clangula americana. GOLDEN-EYE.-This was the most common duck of the Nipigon region, but peculiarly enough only one male was identified during the two summers, viz., on June 28 , 1924, off Murchison island.

Practically all of the small inland lakes harboured at least one family of golden-eyes and they were also found in the mud-bottomed, grassgrown bays. These families usually consisted of a female and from four to six young. The largest number of young observed in one brood was ten. Young were first observed following the female during the last week of June.

A family of golden-eyes resorts to a number of methods of escape when threatened. When the first sign of danger appears the females usually lead the young quickly, but quietly, to the nearest shelter along shore. If this fails to elude the enemy they meet the emergency by 
dashing from their retreat, attempting to put distance between them and their pursuer in order to repeat their ruse. However, if hardpressed, their next resort is to dive. If chase is continued after each member as it reappears on the surface of the water, it dives again immediately and the whole family is soon lost completely, scattered and submerged in all directions. Once or twice while watching this performance I have been able to detect a submerged bird come to the surface and disappear again in a flash, hardly disturbing the water about it. This method of taking air (and keeping sight of an enemy) is difficult to detect but is probably more common than the supposed method of protruding the bill above the surface of the water. Females usually remain with their young when alarmed, but on one or two occasions I have known them to fly. The young are capable of evading ordinary dangers by the method described above but at least one other method is practised when they are still very young. On June 29, 1924, a female golden-eye was observed in open water with two newly-hatched young. When the young became tired by the rapid pace set by the female she retarded her progress and allowed them to climb on to her back, where she carried them for a considerable distance. The young of this species were still flightless when field work was discontinued, during the second week of August, 1924; a specimen taken on August 9 having the under feathers of the body well developed, while the back, except the scapulars, which were well developed, was covered with down. The rectrices were nearly fully developed, while the flight-feathers were very imperfectly so.

2 Juv. ㅇ July 10, 1923 . Newt lake.

Juv. $0^{7}$ July 10, 1923. Newt lake.

\& July 14, 1923. Macdiarmid.

ᄋ July 17, 1923. Macdiarmid.

Juv. $\&$ July 20, 1923. Fairloch.

○ July 20, 1923 . Fairloch.
Juv. + June 29, 1924. Humboldt bay.

ㅇ July 3,1924. Macdiarmid.

o July 4, 1924. Naonan island.

2 Juv. ? July 15, 1924. Chief bay.

Juv. ? July 26, 1924 . Orient bay.

Juv. ㅇ Aug. 9, 1924 . Humboldt bay.

Oidemia deglandi. WHITE-WINGED SCOTER.-On June 18, 1924, five of these ducks were seen on Ombabika bay. It is not known whether the species breeds within the area or not as this was the only occasion on which it was seen during the two summers.

Botarus lentiginosus. BITTERN.-In the more heavily vegetated bays and in the grassy borders of some of the inland lakes bitterns were occasionally flushed.

The species breeds in these situations, a nest with four fully feathered young having been found near a small lake northeast of Macdiarmid, on July 23, 1924. Another nest, abandoned, and probably of the preceding year, was found at Humboldt bay in late June, 1924. 
The bittern may feed a considerable distance from its breeding ground as is known to be the case with other members of its family. One individual was frequently seen flying from its nesting place to the mouth of the Pustagone river, two and one-half miles distant, to feed. The trips to the feeding place were usually made about 5 p.m. An unusual observation of this species was made when a bittern was seen to alight in the top of a dead spruce tree and remain perched there for some time.

o July 4, 1923. Bear creek.

○ July 19, 1924. Macdiarmid.
2 Juv. $0^{7}$ July $23,1924 . \quad$ Macdiarmid.

Pisobia minutilla. LEAST SANDPIPER.-One specimen was taken on the rocky shore of Windigo bay on July 26, 1923. Although the specimen was in all probability an early returning migrant, it is included in the present list because of its occurrence in the region during the summer.

ๆ July 26,1923 . Windigo bay.

Totanus melanoleucus. GREATER YELLOW-LEGS.-A crippled individual was found feeding along the muddy banks of Bear creek on June 15, 1924. It was again noted by members of the Fisheries Laboratory later in the season near the same place. This bird, which was incapacitated by a broken leg, was probably unable to reach its breeding grounds to the north and was of accidental occurrence at Lake Nipigon in summer.

Actitis macularia. SPOTTED SANDPIPER.-The spotted sandpiper was common in suitable situations about the lake.

The earliest date on which a full clutch of eggs was found was June 19 , in both years.

Record has been made of some more or less unusual behaviour of this species as noted at Lake Nipigon. (Snyder 1924a).

ơ June 19, 1923. Orient bay. Juv. ơ July 26, 1924. Orient bay.

Oxyechus vociferus. KILLDEER.-The killdeer was not a common bird for the region as a whole, but a pair was usually to be found on the more suitable sandy flats along the shores of some of the bays.

Downy young were seen by the last of June but no nests with eggs were found. The breeding grounds of this species will doubtless be reduced by the projected raising of the lake level.

A newly hatched young held in the hand was observed to have a weak call-note which was an exact imitation of the loud "killdee" 
note of the adult. The adroitness of the young at concealment is no less effective than the behaviour of the parents when the young are in danger. On account of their behaviour it was impossible at times to determine the position of the young within a hundred yards, the parents being concerned as much with one situation as with another.

Juv. \& June 20, 1924. Ombabika bay.

ㅇ June 28,1924 . Humboldt bay.

Canachites canadensis canace. CANADA SPRUCE PARTRIDGE.-There is some variation in the colour of the female specimens secured, most of which can be accounted for by wear. This complicates the subspecific determination of the birds, but geographically the Nipigon region is nearer the range of the subspecies canace than it is to that of canadensis. Insufficient material was available for satisfactory comparison but Mr. Taverner who examined these specimens calls them canace.

The species was not common, none being noted in 1923 .

Newly hatched young were met with on two occasions and specimens were secured.

The notes of the downy young of this species were noted to be very similar to those of a domestic chick.

\% June 21, 1924. Ombabika bay.

Juv.? June 27, 1924. Ombabika bay.

2 Juv.? June 30,1924 . Russell island.

† June 30,1924 . Russell island.

or July 17, $1924 . \quad$ Macdiarmid.

ㅇ Aug. 1, 1924. Macdiarmid.

Bonasa umbellus togata. CANADA RUFFED GROUSE.-Of the seventeen specimens taken, twelve are adults or feathered young. This series is referable to the subspecies togata, the general colour of the upper parts being a grayish brown. There is an interesting variation in the amount of black on the dorsal feathers but this is partially due to wear. The series shows rather uniformly gray tails. The specimens can be matched with birds from southern Alberta and British Columbia as well as from northern and central Ontario.

Grouse were fairly common in the Nipigon region during both summers, being seen regularly near settlements as well as in the wilder parts.

Newly hatched young were first seen by the last week of June.

With one exception all males collected or identified in the field were solitary birds preferring the deeper woods. One male, however, was flushed in company with two hens, both of which, to judge by their behaviour, were concerned with the numerous young which scattered and concealed themselves in the leaves. On June 26, 1924, a downy young grouse, capable of flying ten or fifteen yards, was collected. The wing of this specimen measured $44 \mathrm{~mm}$. 
Juv. ? June 28, 1923. Macdiarmid.

ơ June 14, 1924. Macdiarmid.

$\sigma^{7}$ June $19,1924$. Ombabika bay.

ơ June 21, 1924. Ombabika bay.

4 Juv. ? June 21, 1924. Weatherbe.

q June 21, 1924. Weatherbe.
Juv. ơ June 26, 1924. Ombabika bay.

Juv. ? July 3, 1924. Macdiarmid.

4 Juv.? July 16,1924 . McIntyre bay.

ᄋ July 24, 1924. Macdiarmid.

Juv. $\sigma^{7}$ July 26,1924 . Orient bay.

Circus hudsonius. MARSH HAWK.-This hawk is of rare occurrence in the Nipigon region, only one pair being seen. Open muskeg, or bogs where tree growth is stunted and thin, were not extensive in the region; thus the habitat of the species was limited.

A nest with four eggs and a newly hatched young was collected in an open bog on the north shore of Ombabika bay on June 22, 1924. The nest, made of alder twigs and thickly lined with dry grass, was placed on a slight elevation in the moss.

Juv. ? June 25, 1924. Ombabika bay, (alcoholic).

Accipiter velox. SHARP-SHINNED HAWK.-An adult female was taken on July 22, 1923, at Macdiarmid, and the species was noted on two other occasions, once near Orient bay station in 1923 and again at Black Sturgeon bay in 1924.

No evidence that the species bred in the region was secured.

\& July 22, 1923. Macdiarmid.

Buteo platypterus. BROAD-WINGED HAWK.-This species was the most common hawk of the region, being observed in practically every locality visited. Its characteristic notes were heard almost daily.

The immature bird taken was in badly worn plumage and was seen in company with a bird of mature plumage.

$\sigma^{\top}$ July 5, 1924. Macdiarmid.

Im. $\sigma^{7}$ July 7, 1923. Macdiarmid.

Haliæetus leucocephalus alascanus. NORTHERN BALD EAGLE.-A few pairs were known to occur in the region, two individuals having been seen at Gros Cap on July 14, 1924, and one on the following day at Chief bay.

An almost fully feathered young was secured from a nest on East bay and at least one other nest was known to residents of the region. An adult eagle seen on July 15 , carrying a stick in its talons, was probably enlarging or repairing its nest.

Juv. ? July 8, 1924. East bay.

Falco columbarius columbarius. PIGEON HAWK.-The 
pigeon hawk was found to be fairly common and generally distributed over the area covered.

A nest with two downy young was found on July 2, 1924. It was situated twenty feet from the ground near the trunk of a live white spruce and was composed of barked twigs and lined with moss, cedar-bark fibre, bits of paper and scraps of discarded fish nets.

The adults collected were dark in colour being examples of the dark females and immatures of this form. No light specimens were noted in the field.

2 Juv. ? July 2, 1924. Orient bay.

\& July 2, 1924. Orient bay.

ㅇ July 26,1923 . Windigo bay.

Juv. \& July 27, 1923. White Sand river.

Cerchneis sparveria sparveria. SPARROW HAWK.-This hawk was fairly common and well distributed through the region.

Nests were found in abandoned woodpecker holes during both summers.

A male which was attempting to pick up the downy young of the ruffed grouse was collected on June 21, 1924.
ơ June 21, 1924. Weatherbe.
i July 10, 1924. Macdiarmid.

Pandion haliaëtus carolinensis. OSPREY.-This species was seen during both summers. It appeared to be more common at the northern part of the lake than elsewhere. Its local distribution seemed to depend somewhat on the presence of shallow bays. An osprey was seen feeding on a northern sucker, Catostomus catostomus. This fish is normally found in fairly deep water in the lake but resorts to streams in spring to spawn, and it was from a stream that the osprey in question was seen to take the sucker.

One nest was found situated on the top of a live white spruce some ninety feet from the ground. It was estimated to measure at least four feet in diameter and as much vertically. Although it could not be examined the behaviour of the adults suggested the presence of young.

ㅇ July 5, 1924. Orient bay.

Asio wilsonianus. LONG-EARED OWL.-A single specimen was taken on the north shore of Ombabika bay. The Indians to whom it was shown had never seen the kind before and it appears not to be numerous in the region.

ơ June 24, 1924. Ombabika bay.

Cryptoglaux acadica acadica. SAW-WHET OWL.-We did not meet with this species during either summer at Lake Nipigon but Dr. 
Walter Koelz collected two young in the Kirtland's owl plumage, one of which is in the Museum of Zoology, University of Michigan. These young were taken on July 21, 1922, near Macdiarmid and were probably reared in that vicinity.

Bubo virginianus pallescens. WESTERN HORNED OWL.Two juvenile specimens were secured. Mr. P. A. Taverner, to whom they were submitted, refers them to the subspecies pallescens within the A. O. U. meaning of the name. He remarks that, "It is evident that this north Lake Superior country is out of the breeding range of the red eastern B. v. virginianus". An adult seen in the field but not secured impressed the writer as being a strikingly grey bird, noticeably different from the typical eastern form.

The species was known to breed in at least two localities on Lake Nipigon, near Macdiarmid, and a mile or two up Bear creek.

Juv. $\&$ June 23, 1923. Macdiarmid. Juv. ○̛ June 23, 1923. Macdiarmid.

Ceryle alcyon alcyon. BELTED KINGFISHER.-The species was locally common. It seems probable that it has increased since the railroad was constructed, as it appears to nest exclusively in the sandbanks along the right of way.

Its tunnels were to be found in many of the exposed banks but no evidence was found of its nesting in the crevices in the rock cliffs along the lake shore. A nest examined on July 3, 1923, contained seven partly feathered young.

○ June 20, 1923. Macdiarmid.

Dryobates villosus leucomelas. NORTHERN HAIRY WOODPECKER.-It is evident that the Nipigon birds of this species are intermediate between typical villosus and leucomelas. If 5 inches $(127 \mathrm{~mm}$.) in wing length is accepted as a dividing point between the two forms, two specimens collected are readily referable to the latter while a third specimen tends very slightly to the former. The measurements of the culmens exhibit an intermediate tendency. With the slight evidence in favour of leucomelas the specimens are referred to that subspecies.

Hairy woodpeckers were not common at Lake Nipigon although they were seen at a number of localities. They were not nearly so frequently met with as was the downy woodpecker.

The species breeds in the region, a scattered brood having been seen at Windigo bay on July 26, 1923.

Juv. $\&$ July 26,1923 . Windigo bay.

ơ June 4, 1924. Macdiarmid.

\& June 6, 1924. Macdiarmid. 
Dryobates pubescens medianus. DOWNY WOODPECKER.This was the most common of the woodpeckers of the region, being especially in evidence in the mixed forest where there was standing dead birch.

A number of nests were found, especially late in the season when the hungry young in the nest were particularly noisy. The three juveniles collected were carefully sexed and the crown markings were found to indicate the sex as previously suggested by the writer. (Snyder 1924b.)

ơ June 12, 1923. Macdiarmid. Juv. ? July 16, 1924. McIntyre bay.

ơ July 12, 1924. Macdiarmid. Juv. $ᄋ$ July 23, 1924. Macdiarmid.

Juv. 아 July 16, 1924. McIntyre bay. 우 Aug. 5, 1924. Shakespeare island. Juv. $\sigma^{\top}$ July 16, 1924. McIntyre bay.

Picoides arcticus. ARCTIC THREE-TOED WOODPECKER. -This three-toed woodpecker was not an uncommon species. It frequented both the mixed forest and the black spruce forest but was more often seen in stands of dead black spruce.

Two nests were found, one at Bear creek and another on the north shore of Ombabika bay. Both of these were occupied by young.

ㅇ June 27, 1923. Bear creek.

ơ June 10, 1924. Macdiarmid.

○ July 12, 1924. Macdiarmid.

Sphyrapicus varius varius. YELLOW-BELLIED SAPSUCKER. - This species was rare, having been noted at only three localities.

A family seen at McIntyre bay was the only evidence that the species breeds in this area.

Juv. o' July 16, 1924. McIntyre bay.

Phlœotomus pileatus abieticola. NORTHERN PILEATED WOODPECKER.-This woodpecker was generally distributed throughout the heavily forested areas but was not numerous in any section.

A nest containing two young was found in the trunk of a live aspen on St. Paul island, and a pair nested in a dead paper birch in the clearing at Macdiarmid.

A large charred stump which stood in the clearing at Macdiarmid was used daily in the early part of the summers of 1923 and 1924, by a male pileated woodpecker, as a "drumming post". The loud, slightly accelerated rapping was alternated with the boisterous, flicker-like call of the species. Occasionally individuals were flushed from near the ground where they were feeding. Their large tapered drillings were found at the bases of living white cedars showing the remarkable ability of the species to locate insect-infected spots in green wood. 
๑7 June 25, 1923. Orient bay.

Juv. ơ July 14, 1924. St. Paul island.

Juv. \& July 14, 1924. St. Paul island.

Colaptes auratus borealis BOREAL FLICKER.-Geographically the Nipigon birds belong to the subspecies borealis although one specimen taken is not as large as the average for that form. The other however, is a large bird measuring $317 \mathrm{~mm}$. in length and $36 \mathrm{~mm}$. along the culmen.

Flickers were quite frequently found in and about clearings and on a few occasions were met with in the wilder parts of the mixed forest.

A number of flicker nests were found, one of more than ordinary interest having been located in a dead stub in a clearing south of Orient Bay station; the entrance was but eighteen inches from the ground and the young, which were nearly ready to leave the nest, were almost at ground level when at the bottom of the nesting chamber.

ơ June 22, 1924. Ombabika bay. $\quad \sigma^{\top}$ July 3, 1923. Macdiarmid.

Chordeiles virginianus virginianus. NIGHTHAWK.-The nighthawk was not a common bird of the region as a whole.

Two immature specimens were secured at Macdiarmid and what was thought to be a family was seen nightly, feeding over our camp clearing at Ombabika bay during the last week of June, 1924.

During the breeding season the species was very silent, neither vocal nor mechanical sounds having been heard from the birds observed.

2 Juv. ? Aug. 19, 1923. Macdiarmid.

Archilochus colubris. RUBY-THROATED HUMMINGBIRD. - The species was seen during both summers at Macdiarmid but was not common in the region as a whole.

The flowering plants about the houses at Macdiarmid attracted adults throughout the summer but no evidence was secured as to whether the species bred in the region.

Juv. ơ Aug. 11, 1923. Macdiarmid.

Tyrannus tyrannus. KINGBIRD.-The kingbird appeared to be a rare and irregular summer resident of the Lake Nipigon region. It was seen at Macdiarmid by Mr. N. K. Bigelow during the summer of 1922 , and by us during the summer of 1924 , but no other records of its occurrence in the region were secured.

q June 7, 1924. Macdiarmid. 
Sayornis phœbe. PHEBE.-At least two pairs of phœbes were found near the settlement at Macdiarmid but none were seen elsewhere.

Two nests were discovered, one being situated against the side of a $\log$ building and the other against the face of a rock cliff over the water. Both nests contained young.

5 Juv. ? July 7, 1924. Macdiarmid (alcoholic). Juv. \& July 12, 1924. Macdiarmid. \% July 7, 1924. Macdiarmid.

Nuttallornis borealis. OLIVE-SIDED FLYCATCHER.-This species was well distributed through the stands of black spruce and was consequently more common at the north end of the lake where these woods were more extensive.

While watching an olive-sided flycatcher through the binoculars it was noted that the white tips of the flank feathers are sometimes exposed on each side of the rump from beneath the wing. The song of the species, whip-whēo is a characteristic sound of the desolate spruce forests.

\section{ơ June 27,1923 . Bear creek.}

Tmpidonax flaviventris. YELLOW-BELLIED FLYCATCHER. - These flycatchers were found in many of the moist inland ravines where alders covered the bottom. They were not common but appeared to be well distributed throughout the region.

The song of this flycatcher is suggested by the syllables, sōo-e $\bar{e}$.

ㅇ June 13, 1924. Macdiarmid.

ণ̛ June 16, 1923. Macdiarmid.

Empidonax trailli alnorum. ALDER FLYCATCHER.-This species was not common but was frequently heard or observed in the alder and willow flats near the lake and along streams.

A pair which behaved as if they were nesting was frequently seen at Cedar creek near Macdiarmid but no positive evidence that they nested there was secured.

Two notes of the species were recorded in the field; one, a wēe- $b \bar{e} \bar{e}$, the second syllable being a slightly ascending slur, and the other, a $b e$ $z \bar{e} \bar{e} \bar{o} \bar{o}$, it being an emphatic utterance with the accent on the second syllable and slurred slightly downward.

During a period of about three weeks (the first three weeks in July) the species was silent but later their characteristic notes were again heard.

$0^{7}$ June 18, 1923. Orient Bay station.

\& July 24, 1924. Macdiarmid.

2 or July $24,1924$. Macdiarmid. 
Empidonax minimus. LEAST FLYCATCHER.-The least flycatcher was the most common representative of its family, being found in all suitable localities visited.

A freshly completed nest was found near Macdiarmid on June 9, 1924. It was situated about twenty feet from the ground in a crotch near the trunk of a paper birch which stood at the edge of an alder thicket. On June 16 the nest contained two fresh eggs and on June 22 the clutch contained four eggs.

ơ June 18, 1923. Orient Bay station. Juv. ? July 21, 1924. Fairloch.

or July 11, 1923. Macdiarmid. Juv. ơ July 23, 1924. Macdiarmid.

Cyanocitta cristata cristata. BLUE JAY.-The species was not common and was seen at only three localities in the region,-Macdiarmid, St. Paul island and McIntyre bay.

व7 June 13, 1924. Macdiarmid.

Perisoreus canadensis canadensis. CANADA JAY.-In the wilder sections Canada jays were frequently met with and on a few occasions they wandered into the clearing at Macdiarmid but did not stay long.

Young of the year were collected, these very probably being reared in the region.

The species was not found to be as fearless and familiar as they are reputed to be in the winter season. In fact they were inclined to be retiring in their habits.

$\sigma^{7}$ June 25, 1923. Macdiarmid. Juv. $\sigma^{7}$ Aug. 5, 1924. Shakespeare island. Juv. $\odot$ July 16, 1924. McIntyre bay.

Corvus corax principalis. NORTHERN RAVEN.-Six of these birds were seen near the railway north of Ombabika bay on June 27, 1924. This was the only occasion on which the species was seen by us. Ravens were not known by residents of the region.

Corvus brachyrhynchos brachyrhynchos. CROW.-The crow was more or less common throughout the region.

Nests were found near Macdiarmid but none was seen elsewhere. Young were not seen with the parent birds until the second week of July of both years.

In late July the crows congregated near Macdiarmid and made frequent flights across the bay where they fed on the offal thrown from 
the fishing vessels. They also patrolled the boulder-strewn shores near Macdiarmid acting as scavengers for the village.

ㅇ June 12, 1923. Macdiarmid.

Juv. \& July 18, 1924. Macdiarmid.

\& July 18, 1924. Macdiarmid.

Juv. ? July 18, 1924. Macdiarmid.

or July 18,1924 . Macdiarmid.

Molothrus ater ater. COWBIRD.-The male cowbird collected was the only individual seen during the two summers. The species has probably never been established in this heavily wooded region.

o' June 11, 1923. Macdiarmid.

Xanthocephalus xanthocephalus. YELLOW-HEADED BLACKBIRD.-A single specimen of this species was collected and no others were seen. The individual secured was in breeding condition but it was probably an unmated bird which had wandered slightly out of its normal summer range.

ơ June 20, 1923. Macdiarmid.

Agelaius phœniceus fortis. THICK-BILLED RED-WING.The three specimens collected were examined by Mr. Taverner who remarks that they "seem ultra typical of the mid-western form fortis of the A.O.U. (Check List) or arctolegus of Oberholser".

The species is an uncommon summer resident of the Lake Nipigon region as a whole. The only specimens seen by us which were unquestionably summer residents of the area were a pair at Humboldt bay and a male on the northwest shore of Ombabika bay. Mr. W. J. K. Harkness of the Fisheries Research Laboratory observed the species at the mouth of the Gull river where it appeared to be established in some numbers.

The pair noted at Humboldt bay (June 28, 1924) were breeding birds, the nest having just been completed when found. This was the only pair to occupy a reedy bay covering perhaps one hundred acres.

A specimen taken at Macdiarmid on June 3, 1924, was not an established bird in that locality but a migrant that had not reached its breeding grounds. The migratory movements of many species are not usually concluded along the latitude of the Transcontinental Railway until about the first of June.

o June 3, 1924. Macdiarmid.

ㅇ June 28,1924 . Humboldt bay.

ơ June 28, 1924. Humboldt bay.

Euphagus carolinus. RUSTY BLACKBIRD.-An injured female was taken at Macdiarmid in 1924 and a flock on their southern migration was seen at Humboldt bay the same year. 
No resident birds were seen by us and it seems probable that the species does not breed in the immediate vicinity of Lake Nipigon.

\author{
\& June 2, 1924. Macdiarmid.
}

Quiscalus quiscula æneus. BRONZED GRACKLE.-This species was seen in early June of both years but after all migratory movements had ceased it was not again noted.

Carpodacus purpureus purpureus. PURPLE FINCH.-The purple finch occurs fairly commonly throughout the region.

Young of the year were collected from flocks which began to be conspicuous after the second week in July.

$\sigma^{7}$ July 2, 1923. Macdiarmid.

o July 11, 1923. Macdiarmid.

Juv. क July 18, 1923. Macdiarmid.

○ June 7, 1924. Macdiarmid. Im. ơ July 12, 1924. Macdiarmid.

Astragalinus tristis tristis. GOLDFINCH.-The species was found to be only fairly common locally. At Macdiarmid, late in the summer, flocks of from six to fifteen individuals were seen during both years.

Pairs were seen in July which behaved as if they were engaged in nesting duties, but no other evidence that this species bred in the region was secured.

○ July 11, 1924. Macdiarmid.

Spinus pinus. PINE SISKIN.-These birds were seen in small flocks of five or six by the middle of June and as the season advanced the flocks increased in size. These small flocks may or may not have been family groups but collecting from one such group suggests that such was not the case, since three adults were secured.

It would be difficult to state at what season this species breeds since they seem to flock throughout the summer. A young of the year was secured.

Juv. $\sigma^{7}$ Aug. 1, 1923. Macdiarmid.

2 \% June 14, 1924. Macdiarmid.

ơ June 14, 1924. Macdiarmid.

Passer domesticus. HOUSE SPARROW.-Eleven individuals were known to be resident at Macdiarmid during July, 1923. During the same month in 1924 twenty-six were noted, while the species had also spread to the new clearing about the lumber mill, one and one-half miles north of Macdiarmid. This latter record is of interest since the clearing had been only recently made, the buildings having been erected during the winter of 1923-24. 
House sparrows nested in the ventilator cupola of the ice-house at Macdiarmid. The species is likely to increase as other buildings afford nesting sites, and food will be present as long as horses are maintained for the fishing and lumbering industries.

\& June 18, 1923. Macdiarmid. क्ञ July 10, 1924. Macdiarmid.

Poøcetes gramineus gramineus. VESPER SPARROW.-The vesper sparrow was not seen in 1923 but two individuals were noted during early June, 1924. In a clearing made during the winter of 1923-24 for a lumber mill all debris had been burned leaving approximately eighty acres of bare field. A singing male was taken there on June 5th.

or June 5, 1924. Macdiarmid.

Passerculus sandwichensis savanna. SAVANNAH SPARROW. -The two specimens taken were submitted to Mr. Taverner who says, "These Nipigon birds may tend toward a northern form that has long been suspected. On superficial survey, would not be certain that they are not savanna". The Nipigon birds are accordingly tentatively referred to that subspecies.

Single individuals, or pairs, were noted at three localities on the lake.

The behaviour of a pair seen at Ombabika bay on June 25, 1924, suggested the presence of a nest but none was found.

के June 25, 1924. Ombabika bay.

$\sigma^{7}$ July 2, 1924. Orient Bay station.

Passerherbulus lecontei. LECONTE'S SPARROW.-Although this species was looked for it was not seen by us. Koelz (1923) has recorded the capture of a juvenile female taken in a mouse trap at Macdiarmid on July 27, 1922. This record was erroneously attributed to Harris' sparrow by Taverner (1927).

Zonotrichia albicollis. WHITE-THROATED SPARROW.This was the commonest bird in and about all natural and artificial clearings.

A number of nests were found each summer and it seems that the species is one of the few birds of the Canadian zone which rears more than one brood in a season.

About fifty per cent. of singing white-throated sparrows were heard to prelude their usual song with three short "take-up" notes all on the same pitch and given in rapid succession.

† June 14, 1923. Macdiarmid.

or June 14, 1923. Macdiarmid.

ơ July 3, 1924. Macdiarmid.

or July 10, 1924. Shakespeare island.

¡ July 8,1924 . Shakespeare island. Juv. ? July 16, 1924. McIntyre bay. Juv: ? July 24, 1924. Macdiarmid. ㅇ July 26, 1924. Orient Bay station. 
Spizella passerina passerina. CHIPPING SPARROW.-This was a fairly common bird about inhabited clearings. It was seen on one occasion in a situation far from settlement.

Adults with partly fledged young were frequently seen about our camp at Macdiarmid after the middle of July.

$\begin{array}{llll}\text { ơ June 25, 1923. } & \text { Macdiarmid. } & \text { Juv. ? July 17, 1923. } & \text { Macdiarmid. } \\ \text { ơ July 4, 1924. } & \text { Macdiarmid. } & \text { Juv. } \text { ? July 25, 1924. } & \text { Macdiarmid. } \\ \text { के July 12, 1924. } & \text { Macdiarmid. } & \text { Juv. ? July 28, 1924. } & \text { Macdiarmid. }\end{array}$

Junco hyemalis hyemalis. SLATE-COLORED JUNCO.-Specimens were submitted to $\mathrm{Mr}$. Taverner who remarks that they tend "toward the black-headed hyemalis Swarth (1922) found on the Stikine River, B.C.- - but are not as decided".

Juncos were not common but were generally distributed being found in the drier clearings and on exposed, rocky hilltops.

A nest with four partly incubated eggs was found on June 26, 1924, at Ombabika bay.

$\sigma^{7}$ July 7, 1923. Macdiarmid.

Juv. ? July 11, 1923. Macdiarmid.

ơ July 11, 1923. Macdiarmid.

or June 9, 1924. Macdiarmid.

2 June 26, 1924. Ombabika bay.

व̛ June 27, 1924. Ombabika bay.

Melospiza melodia juddi. DAKOTA SONG SPARROW.-On comparing a series of thirteen adults from Lake Nipigon with a series from southern Ontario, the former are at once distinguishable by the lack of reddish colour and in having the black markings, especially on the feathers of the back, broader and more intense. The dark markings on the breast are somewhat sharper in outline. Insufficient summer material is at hand for a satisfactory comparison with birds from the prairie provinces but specimens in the collection of Mr. J. H. Fleming from southern Saskatchewan are slightly greyer and exhibit somewhat less black than Nipigon birds. On the other hand specimens from northern Saskatchewan appear to be the same as Nipigon specimens. After a comparison with material from northeastern North Dakota recently added to the Museum's collection, I am convinced that the Nipigon birds should be referred to juddi. Mr. Taverner who examined the series states, "These Nipigon birds unmistakably run in with our prairie specimens that I have called juddi".

Song sparrows were common in all suitable situations.

Both nests and eggs as well as juveniles were collected.

\% July 9, 1923. Macdiarmid.

o June 6, 1924. Macdiarmid.

or June 6, 1924. Macdiarmid.

\& June 7, 1924. Macdiarmid.

$30^{7}$ June 7, 1924. Macdiarmid.

o June 22, 1924 . Ombabika bay.

† June 23, 1924. Ombabika bay.

$\sigma^{7}$ June 29, 1924. Humboldt bay.

or July 7, 1924. Miacdiarmid.

of July 18, 1924. Macdiarmid.

Juv. $\&$ July 19, 1924 . Macdiarmid.

ㅇ July 24, 1924. Macdiarmid.

Juv. $\&$ July 30,1924 . Orient Bay station. 
Melospiza lincolni lincolni. LINCOLN'S SPARROW.-This species was present in many of the clearings, two or three pairs sometimes being found in a partial clearing of not more than two or three acres in extent.

We were not fortunate enough to locate a nest although an adult was seen carrying nesting material. Young just out of the nest, were seen on several occasions, and one was secured.

Males were heard singing occasionally during midday but their usual habit was to sing for a few moments from some low perch just after daybreak and again just before dark. The song suggests the bubbling theme of the house wren but has the unquestionable quality of a finch or sparrow.
ơ June 14, 1923. Macdiarmid.
ơ July 6, 1923 . Macdiarmid.
Juv. ? July 4, 1924. Macdiarmid.
or July 9, 1923. Macdiarmid.
2 우 July 4, 1924. Macdiarmid.

Melospiza georgiana. SWAMP SPARROW.-This was a common species in suitable situations.

Young just out of the nest were seen on several occasions.

ơ June 27, 1923. Orient Bay station. Juv. o July 31, 1923. Orient Bay station.

ơ June 21, 1924. Ombabika bay. कृ July 23, 1924. Macdiarmid.

Hedymeles ludovicianus. ROSE-BREASTED GROSBEAK.A male taken at Macdiarmid was the only record of the occurrence of the species in the region.

万ొ June 10, 1924. Macdiarmid.

Iridoprocne bicolor. TREE SWALLOW.-This swallow was fairly well distributed throughout the region but was not particularly common in any locality.

Two nests were found at Macdiarmid, both located in abandoned woodpecker holes in dead trees near the water.

ơ June 14, 19233. Macdiarmid.

Bombycilla cedrorum. CEDAR WAXWING.-Flocks of from ten to twenty individuals were regularly seen until the last of June when they separated into pairs.

Although no nests were found, young birds were observed in late July and early August.

Oొ June 18, 1923. Macdiarmid.

$\sigma^{7}$ July 31, 1924. Macdiarmid.

ơ Aug. 8, 1924. Humboldt bay. 
Vireosylva olivacea. RED-EYED VIREO.-This species was common throughout the poplar growths of the region.

A nest containing two newly hatched young and two eggs was found on July $18,1923$.
$\sigma^{7}$ June 13, 1923. Macdiarmid.
$0^{7}$ July 18,1924 . Macdiarmid.
† June 22, 1924 . Ombabika bay.

Vireosylva philadelphica. PHILADELPHIA VIREO.-To judge from the number of occasions on which it was positively identified this species appeared to be almost as common as the red-eyed vireo.

A pair was observed carrying nesting material on June 19, 1923.

The song was distinguishable from that of olivacea, being about a musical fifth higher in pitch with a slightly longer pause between phrases.

ㅇ June 19, 1923. Orient Bay station. OT June 21, 1924. Ombabika bay.

$\sigma^{7}$ June 9, 1924. Macdiarmid.

Lanivireo solitarius solitarius. BLUE-HEADED VIREO.This species was not infrequently met with in the mixed forest.

ơ June 27, 1923. Bear Creek.

or June 9, 1924. Macdiarmid.

Mniotilta varia. BLACK AND WHITE WARBLER.-This warbler was common in many localities visited.

2 ơ June 11, 1923. Macdiarmid.

of June 4, 1924. Macdiarmid.

कึ June 9, 1924. Macdiarmid.

Vermivora ruficapilla ruficapilla. NASHVILLE WARBLER.This was another common species, well distributed throughout the region.

It doubtless breeds throughout the area. Young being fed by the parents were observed on several occasions late in July at Macdiarmid.

$\sigma^{T}$ June 9, 1924. Macdiarmid. 2 Juv. $ᄋ$ July 18, 1924. Macdiarmid.

ㅇ June 24,1924 . Ombabika bay. 2 J July 18,1924 . Macdiarmid.

Vermivora celata celata. ORANGE-CROWNED WARBLER.A few pairs were noted at Ombabika bay but the species was not observed elsewhere.

Its song is a musical trill not unlike that of the junco but sufficiently different to attract one's attention to the bird.

จ June 24, 1924. Ombabika bay.

Vermivora peregrina. TENNESSEE WARBLER.-This was a common species throughout the region, found foraging through all types of forest growths. 
A nest containing four incubated eggs was collected on July 21, 1924. It was composed of dry grasses and situated in the side of a clump of sphagnum moss slightly elevated above the surrounding bog. This nest which was taken by $\mathrm{Mr}$. Baillie appears to be the first collected in Ontario.

The song of this species is an accelerated cut-sic, cut-sic, cut-sic, cuwitcha, witcha, witcha, witcha, see-see-see-see-see. A male collected on July 16, 1923, has a fairly evident crown patch of chestnut-brown, like that of ruficapilla. Such a marking is unusual but has been previously reported by Lloyd (1917).
o July 16,1923 . Macdiarmid.
or July 17, 1923. Macdiarmid.
ơ June 5, 1924. Macdiarmid.
of July 19, 1924. Macdiarmid.
\& July 21, 1924. Fairloch.

Dendroica tigrina. CAPE MAY WARBLER.-A single singing male taken on Shakespeare island is the only record of the species in the region.

ণ7 July 8, 1924. Shakespeare island.

Dendroica æstiva æstiva. YELLOW WARBLER.-This warbler was not common at Lake Nipigon, only a few birds having been seen at scattered localities.

The species breeds in the alder-and willow-covered flats of both the mainland and the islands. Young birds were seen being fed by the parents.

ㅇ July 31, 1923. Orient Bay station. $\quad$ July 14, 1924. Gros Cap.

ơ June 20, 1924 . Ombabika bay.

Dendroica coronata. MYRTLE WARBLER.-This warbler was not common in the region as a whole but in one or two localities it was seen in some numbers.

The species breeds in the region, partially fledged young having been secured.

o June 21, 1923. Naonan island.

ơ July 16, 1924. McIntyre bay.

ơ Aug. 1, 1924. Macdiarmid. o Aug. 5, 1924. Shakespeare island. Juv. ? Aug. 8, 1924. Humboldt bay. Juv. ? Aug. 9, 1924. Humboldt bay.

Dendroica magnolia. MAGNOLIA WARBLER.-This was the most abundant and generally distributed warbler and at times appeared to be the most common bird of the region.

The species breeds throughout the area, families of noisy young being frequently met with during late July.

o June 14, 1923. Macdiarmid.

$\sigma^{7}$ June 9, 1924 . Macdiarmid.
Juv. ? July 24, 1924. Macdiarmid. ơ July 24, 1924. Macdiarmid. 
Dendroica pensylvanica. CHESTNUT-SIDED WARBLER.This warbler was common in three locations along the southern end of Lake Nipigon but was not recorded from any of the stations at the northern end of the lake. This observation appears to indicate that this characteristic species of the Transition zone reaches its northern limits at Lake Nipigon.

ơ June 11, 1923. Macdiarmid.

$\sigma^{7}$ July 2, 1924. Orient Bay station.

๑ July 23, 1924. Macdiarmid.

Dendroica castanea. BAY-BREASTED WARBLER.-This was a fairly common species of the region.

The song of the bay-breasted warbler is very similar to the notes of the golden-crowned kinglet but is composed of five whispered notes instead of three.

o7 June 5, 1923. Macdiarmid.

o7 June 27, 1923. Bear creek.

o July 4, 1923. Macdiarmid. ơ July 8,1924 . Shakespeare island.

ㅇ July 16, 1924. McIntyre bay.

ㅇ Aug. 8, 1924. Humboldt bay.

Dendroica fusca. BLACKBURNIAN WARBLER.-This warbler was not very common at Lake Nipigon.

A family of young was observed at Macdiarmid in 1923 and partly fledged young were secured in 1924 .

$\sigma^{7}$ June 28, 1923. Macdiarmid.

\& July 24, 1924. Macdiarmid.

o July 23, 1924. Macdiarmid.

Juv. + July 24, 1924. Macdiarmid.

Juv. ? Aug. 9, 1924. Humboldt bay.

Dendroica virens. BLACK-THROATED GREEN WARBLER.This was a common species of the mixed forest.

Young were observed being fed by the adult.

○ౌ July 2, 1923. Macdiarmid. Juv. ? July 25, 1924. Macdiarmid.

ơ July 8, 1924. Shakespeare island. Juv. ơ Aug. 3, 1924. Macdiarmid.

Seiurus aurocapillus. OVEN-BIRD.-This species was fairly common in the mixed forest.

A partly fledged young, just out of the nest, was secured at McIntyre bay in 1924 .

o June 11, 1923. Macdiarmid.

or July 12, 1924. Macdiarmid.

Juv. ? July 16, 1924. McIntyre bay.

\& July 21, 1924. Fairloch.
Ơ July 25, 1924. Macdiarmid.

Juv. $\&$ July 26,1924 . Orient Bay station.

or July 26, 1924. Orient Bay station.

Seiurus noveboracensis notabilis. GRINNELL'S WATERTHRUSH.-The single specimen secured agrees well with the colour 
distinctions of notabilis; in fact it is more typical of that form than birds from farther west with which it was compared.

Water-Thrushes were rather uncommon being heard at only a few places on the lake, and they were seldom seen.

ơ June 25, 1924 . Ombabika bay.

Oporornis agilis. CONNECTICUT WARBLER.-This species was seen only at Ombabika bay where two singing males were noted in a black spruce growth.

The song was a loud ca, chicka-chicka, chicka-chicka, chicka-chicka, reminding one of the song of the Maryland yellow-throat.

フ June 27, 1924. Weatherbe.

Oporornis philadelphia. MOURNING WARBLER.-This was a common species of the clearings. The number of these birds was particularly striking, a feature also noticed by Dr. Koelz during his stay on the lake in 1922.

A nest with a partial set of eggs was found at Macdiarmid on June 29, 1923, but it was destroyed before the set was completed. A young bird just out of the nest was collected.

Breeding males show a great variation in the amount of black on the upper breast and throat. It appears, from specimens secured, that as the season advances and the feathers become worn the black extends from the upper breast to the base of the bill. A male collected on July 11, 1924, which showed by dissection that it was in breeding condition had a few black and yellowish feathers on the throat while the breast was similar to that of a female.

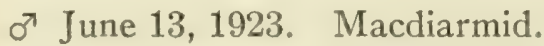
or July 11, 1924. Macdiarmid.
ơ July 12, 1924. Macdiarmid.
\& July 16, 1924. McIntyre bay.
\& July 23, 1924. Macdiarmid.
2 구 July 23, 1924. Macdiarmid.
Juv. + July 24, 1924. Macdiarmid.
$\sigma^{7}$ July 28, 1924. Macdiarmid.
ㅇ Aug. 2, 1924. Macdiarmid.

Wilsonia pusilla pusilla. WILSON'S WARBLER.-At the time of our arrival at Macdiarmid on June 2, 1924, migratory movements had not yet ceased. Wilson's warbler was one species which was taken at Macdiarmid during the first week of June and then disappeared from the southern end of the lake. The species was rare in the region as a whole, but a few were noted on the northwest shore of Ombabika bay late in June.

No positive evidence as to whether the species breeds in the locality was secured.
2 ㅇ June 7, 1924. Macdiarmid.
ণึ June 22, 1924. Ombabika bay. 
Wilsonia canadensis. CANADA WARBLER.-This common warbler was noted in heavily wooded situations and also in partially overgrown clearings.

A partially feathered young was taken.

ơ June 14, 1923. Macdiarmid. Juv. $\sigma^{\top}$ July 25, 1924. Macdiarmid.

ơ June 10, 1924. Macdiarmid.

Setophaga ruticilla. REDSTART.-This species was common at all points visited.

Both nests and young were observed.

The song of the redstart was variable. One individual which sang from the same general location at the edge of the clearing at Macdiarmid repeated incessantly an ascending, hissing trill.

ㅇ June 5, 1924. Macdiarmid.

ơ June 18, 1923. Macdiarmid.

ơ July 23, 1924. Macdiarmid.
Juv. ఠ̛ July 31, 1924. Macdiarmid.

ㅇ July 31,1924 . Macdiarmid.

Troglodytes æ̈don parkmani. WESTERN HOUSE WREN.The skin of a male specimen has been compared with eastern and western birds and it is strikingly greyer than those from the east. Mr. Taverner confirms the opinion that it is well marked parkmani. But one pair of house wrens was noted during the two summers.

This pair was nesting about the debris from an old railway construction camp of the railway, east of Weatherbe.

$\sigma^{\top}$ June 27,1924 . Weatherbe.

Nannus hiemalis hiemalis. WINTER WREN.-This species was well distributed throughout the region being found for the most part in the darker ravines and in dense cedar growths with fallen trees.

ơ June 28, 1923. Macdiarmid.

or July 22, 1924. Macdiarmid.

Certhia familiaris americana. BROWN CREEPER.-This was not a common species but it was seen at three localities in the southern part of the area.

A partly fledged young was collected with the parent female at Shakespeare island.

Juv. ? July 14, 1923. Macdiarmid. o July 8, 1924. Shakespeare island. Juv. ? July 8, 1924. Shakespeare island. ? Aug. 4, 1924. Shakespeare island.

Sitta canadensis. RED-BREASTED NUTHATCH.-This species was not infrequently observed in stands of mixed forest where occasional dead tree trunks were standing. 
The species breeds in the region, adults having been seen on several occasions carrying food into old woodpecker holes high up in dead trees.

\& July 2, 1923. Macdiarmid. ơ July 10, 1924. Shakespeare island.

Penthestes atricapillus septentrionalis. LONG-TAILED CHICKADEE. Adults secured were long-tailed birds lacking ochraceous colour on their backs. Mr. Taverner who examined the specimens agrees that they are referable to the subspecies septentrionalis.

Chickadees were fairly common in the region.

A nest was found on June 7, 1924 in an abandoned woodpecker hole near the top of an eight foot stump standing in shallow water. Family groups were frequently seen by the second week in July.

ơ June 11, 1923. Macdiarmid.

ơ July 19, 1923. Macdiarmid.

Juv. ? July 11, 1924. Macdiarmid.
Juv. \& July 11, 1924. Macdiarmid.

Juv. $\sigma^{7}$ July 11, 1924. Macdiarmid.

Penthestes hudsonicus hudsonicus. HUDSONIAN CHICKADEE.-This chickadee was an uncommon species having been observed at but two widely separated localities.

Young were collected from families foraging through a dense, wet woods near Macdiarmid.

The notes of this species are similar to those of the other chickadee of the region but are hoarser and have a buzzy quality.

Juv. ? July 9, 1923. Macdiarmid. Juv. or July 22, 1923. Macdiarmid.

† July 9, 1923. Macdiarmid.

Regulus satrapa satrapa. GOLDEN-CROWNED KINGLET.This was a common bird of the mixed woods where conifers predominated.

A partially fledged young was secured.

ㅇ July 14, 1923. Macdiarmid.

of June 27, 1924. Weatherbe.

or July 23, 1924 . Macdiarmid.

ơ July 10, 1924. Shakespeare island.

Juv. $0^{7}$ July 28, 1924. Macdiarmid.

Regulus calendula calendula. RUBY-CROWNED KINGLET. - This was an uncommon species. It was not seen during 1923 and at only one locality in 1924.

$0^{7}$ June 25, 1924 . Ombabika bay.

Hylocichla ustulata swainsoni. OLIVE-BACKED THRUSH. -A specimen collected on June 24, 1924 at Ombabika bay is distinctly gray above, a similar bird to those mentioned by Travener (1919) in "The Birds of Shoal Lake, Manitoba". All the other specimens are normal swainsoni. 
This thrush was common throughout the region but was principally found in the mixed woods, although during the season when raspberries were ripe it frequented the clearings to feed on this fruit.

On June 23, 1924, a nest containing four fresh eggs was found at Ombabika bay. It was situated eighteen inches from the ground in a young spruce. The eggs were left untouched for two or three days to make certain that the clutch was complete but in the meantime the bird deserted the nest and one egg disappeared. Similar experiences have been recorded by other observers and few appear to be satisfactorily explained.
ơ June 11, 1923. Macdiarmid.
or June 22, 1924. Ombabika bay.
ㅇ June 24, 1924 . Ombabika bay.
Juv. ? July 16, 1924. McIntyre bay.
o July 16, 1924. McIntyre bay.
ơ July 18, 1924. Macdiarmid.

Hylocichla guttata pallasi. HERMIT THRUSH.-This thrush was not nearly so common as the preceding and was seen in only three localities. It was found in drier situations.
ơ July 7, 1923. Macdiarmid.
† June 24, 1924 . Ombabika bay.
ơ June 26, 1924. Ombabika bay.
o7 July 16, 1924 . McIntyre bay.

Planesticus migratorius migratorius. ROBIN.-The robin was not common but was generally distributed, a pair having been found in almost all of the settled clearings visited, while individuals were noted also in situations far removed from settlement.

A pair nested in the clearing at Macdiarmid, and a set of eggs was taken near the Transcontinental Railway north of Ombabika bay on June 27,1924 . In this instance the nest was situated on the top of a stump about eighteen inches from the ground in a partial clearing many miles from a settlement.

ơ June 23, 1923. Macdiarmid.

\section{Literature Cited}

Koelz, W. 1923. Some recent records from the Lake Superior region, Ontario. Can. Field-Naturalist, 37: 118.

Lloyd, Hoyes 1917. Ontario bird notes. The Auk, 34: 460.

Snyder, L. L. 1924a. Peculiar behavior of the spotted sandpiper (Actitis macularia). The Auk, 54: 341-342.

Snyder, L. L. 1924b. On the crown markings of immature hairy and downy woodpeckers. Can. Field-Naturalist, 37: 167-168.

Swarth, H. S. 1922. Birds and mammals of the Stikine river region of northern British Columbia and southeastern Alaska. Univ. Calif. Pub. Zool., 24: 243.

Taverner, P. A. 1919. The birds of Shoal lake, Manitoba. Can. Field-Naturalist, 33: 19.

Taverner, P. A. 1927. Some recent Canadian records. The Auk, 44: 225-226. 



\title{
THE AMPHIBIANS AND REPTILES OF THE LAKE NIPIGON REGION
}

\author{
By E. B. S. LOGIER
}

In the summers of 1921,1922 and 1924, the writer visited Lake Nipigon in the capacity of artist to the Fisheries Research Laboratory, Department of Biology, University of Toronto, and it was in those summers, chiefly, that the material and data used in the present paper were collected. Considerable material was also collected by other members of the Fisheries Research Laboratory and of the Royal Ontario Museum of Zoology, especially in the years when the writer was not at Lake Nipigon.

The list presented in the following pages is probably incomplete but this represents the first serious attempt to make a herpetological survey of the region. The only previous list of amphibians and reptiles of this region known to the writer is that of Wilson (1910) who included some faunistic lists in his report on the Geology of the Nipigon Basin. His account is as follows:

"Reptiles: Specimens of the Mud Puppy, Necturus maculatus, and at least two species of salamander, were seen. Several species of toads and frogs occur, but the common frog of more southern parts of Ontario is rare.

"Garter snakes are occasionally seen, and seem to be the only kind of snake found in the district. According to the Indians, a species of tortoise, probably Chremy sp., occur on a small lake, the first west of Black Sturgeon Lake on the Circle Lake System."

Of the forms recorded in the above list, Necturus maculosus was not seen by any of the University of Toronto party during the six summers spent in careful and detailed study of Lake Nipigon and its fishes, so if correctly identified by Wilson, it is evidently of rare occurrence. Mr. Duncan Bell reports seeing it once at McIntyre bay.

Amphibians are fairly well represented at Lake Nipigon, nine species having been found,- - three urodeles and six anurans, and most of them were fairly common. Of the reptiles only two species were found,Bell's turtle and the common garter snake, neither of which was plentiful.

Comparison of the amphibian fauna of the main shores of Lake Nipigon with that of the islands is interesting, since the latter have evidently been isolated since the retreat of the last glacier, precluding 
the possibility of voluntary migration of adults or larvae as this would necessitate, in some cases at least, a swim of several miles in the open lake. All of the species of amphibians found on the islands, viz., Jefferson's salamander, American toad, wood frog, green frog, and leopard frog are species which lay their eggs in strings or masses of jelly either floating free or attached to, or tangled about trash in the water. Eggs laid in this manner might easily be transported by floating, especially if they were attached to any buoyant objects. It is also possible that adult salamanders hibernating in old logs about the margins of streams might be carried out with the high water in the spring, and logs containing them might occasionally reach an island.

The eggs of the newt and the peeper are laid singly, those of the latter species free on the bottom, those of the former folded in the leaves of aquatic plants which are anchored and pliable, and unlikely to become uprooted by current or wave action in the quiet situations which the species selects. These two species seemed to be absent from any of the islands investigated. It is interesting to note in this connection that newts and peepers were not found about the shore waters of Lake Nipigon, even in the most sheltered bays, but resorted to small bodies of impounded water.

The association of amphibian larvae with each other and with fish is to a certain extent restricted by the nature of habitat required by the different species. Ambystoma larvae were not found in company with fish, which is also true of Triturus. Ambystoma and Triturus were found together and in company with tadpoles of Hyla crucifer and Rana clamitans. Ambystoma larvae were also found in water with Bufo americanus and Rana catabrigensis tadpoles. Tadpoles of B. americanus, $H$. crucifer, $R$. cantabrigensis, and $R$. clamitans were found together in the same water.

Except in one case, the tadpoles of $H$. crucifer were not found in company with fish, and in this case the fish in question were young brook sticklebacks and small minnows of one or more species.

\section{Localities}

Owing to the fact that many of the small lakes and streams in the region of Lake Nipigon have no official names, it is necessary to coin names by which to refer to them. A number of these waters are referred to and discussed in Dymond's paper, "The Fishes of Lake Nipigon", (1926), and the names which he used there will be employed in the present paper, a few more being added.

The following is a list of some of the habitats with brief descriptions of physical characters. Of these, Centre lake, Crescent lake, First Station lake, Orient bay and Pustagone river have been described by 
Dymond and some of his data will be included in the following descriptions.

Centre and Crescent lakes lie in the same valley and are separated from each other by a low, marshy area. Crescent lake, the source of Cedar creek, is crescent-shaped, and about 200 yards long by 75 yards wide. The water of these lakes is dark brown, the bottoms are of muck, and the shores, except on the western side, are largely of sphagnum bog. Centre lake is the deeper of the two. The water in Crescent lake is apparently not deeper than three feet.

Muskeg lake lies at the foot of the eastern slope of the hill at Fairloch upon which stands the fire rangers' lookout tower, about three miles north of Macdiarmid. Its greatest length is probably not much more than 100 yards. The shores are of quaking bog, the bottom of muck, and the water is turbid-brown. At the north end there is a sphagnum bog forested with black spruce.

Newt lake is a small lake of irregular shape, with several bays, and not much over a half mile in greatest length. It is situated on a plateau among the hills on the west side of Orient bay, just across from Macdiarmid, and about 250 or 300 feet above Lake Nipigon. It is forested to the water's edge around most of its shores. The bottom is chiefly of mud, but rather firm and stony along much of its southern edge. The west end is shallow and marshy, sustaining a good growth of sphagnum and sedges. A bay at the eastern end narrows to an outlet, and the bottom here is strewn with decaying leaves of alder and poplar. The water is clear.

Orient Bay lake is a small lake about 100 yards in width, near the south end of Orient bay. It lies at the foot of a cliff which forms its eastern shore. The cliff has a rock talus at its base running down to the water. The other shores are low and fringed with speckled alder, and the bottom, at least at the southeastern part, is sandy for a few yards out and then becomes oozy.

First Station lake, situated about a mile northeast of Macdiarmid, lies in a deep valley between two ridges. It is about a half mile long and 150 yards wide, with a sphagnum bog at each end. The sides are rather steeply sloping and forested to the water's edge, except for a short distance where a rock talus forms the shore. The bottom is mostly of soft ooze, though firm and sandy at parts of the shore. The water reaches a depth of six feet and is somewhat brownish. The lake drains by a small stream which enters Orient bay at Macdiarmid. 
Second Station lake lies in the next valley east of First Station lake. It is smaller than the latter. Its shores are margined by a narrow bog which is closely surrounded by the forest, and the bottom is of sof t ooze.

Toad Pond and Pustagone ponds. In the partly dry bed of a side channel near the mouth of the Pustagone river, was a large, shallow pond with mud bottom sloping gently down to a depth of about twenty inches. In some of the shallow places there was a good growth of short, submerged grass, while other aquatic plants such as Potamogeton, Utricularia and yellow pond lilies grew in the deeper parts. It was unshaded and the water became warm on sunny days. Near this "Toad pond" as it shall be called, were some smaller ponds in the same channel bed and in a smaller channel entering it.

C.N.R. pools. Along the sides of the Canadian National road-bed, from a short distance north of Macdiarmid to near the Pustagone river valley, were a number of shallow pools which in rainy weather would drain through each other forming a small stream, but would dry down and separate in dry weather, some of them finally losing all of their water, others retaining some. In some parts of these pools sedges and rushes were growing, in other places the bottom was of bare mud without vegetation of any kind. In some places the water would reach a depth of a foot or more and seemed to be permanent.

Orient bay (Pijitawabic bay), at the southeast corner of Lake Nipigon is about ten miles in length, and narrows gradually southward to a point. At the southern end which is well removed from the influence of the lake and sheltered on both sides by high hills, the water is shallow and quiet and there is much aquatic vegetation. Here are some ponds cut off from the bay by the railroad embankment.

The Pustagone river enters Orient bay about a mile south of Macdiarmid. Much of the bed is stony and the water is, in most places, rather shallow and rapid. Near the mouth the stream forks, but reunites a few hundred feet from the lake, and here the valley is a wide, grassy flat, devoid of trees.

\section{Measurements}

Measurements of the total length of frogs are taken from the tip of the snout to the anus, and those of the hind legs from their insertion in the pelvis to the ankle joint, not to the heel. It was found that measurements taken to the heel varied somewhat depending on whether 
the foot was bent at an angle or drawn out straight. All proportionate measurements are given in percentages of the total length. All measurements were made from preserved specimens.

In the case of the amphibians, discussion of structure and colour are not entered into except where interesting variations from normal occur.

\section{Acknowledgements}

My thanks are due to Dr. A. H. Wright of Cornell University for his kindness in examining and reporting on specimens sent to him, and furnishing many interesting comments on variation in the different species in question; also to Dr. A. G. Ruthven, Museum of Zoology, University of Michigan, who examined the garter snakes.

\section{Amphibians}

Triturus v. viridescens (RAF.). GREEN NEWT.-This species was found to be common in some of the small lakes southeast of Lake Nipigon, but it was not found in any of the bays or marshes of Lake Nipigon itself. It was found in greatest numbers in Newt lake which was visited in July, 1922, 1923 and 1924, and on each occasion this lake contained very large numbers of newts. The species was seen in fair numbers in Orient Bay lake in June 1924, and one specimen was taken at Second Station lake in July of the same year. It appeared to be totally absent from any of the islands investigated.

The life history in this latitude is deserving of some careful study and would be interesting to compare with that in more southern localities.

On June 12,1924, a few males were noted clasping females in Orient Bay lake. On the occasion of the visits to Newt lake in July of three consecutive years no eggs or larvae were found. Egg-laying evidently lasts far into the summer as most of the females examined from the July collections contained ripe ova in varying numbers. The apparent absence of even the smallest larvae in the water at this time of the year would also suggest a late beginning of egg-laying. These facts, when compared with the observations of Gage (1891) and Pope (1924) and considered together with the shortness of the northern summer, would suggest the probability, especially in the case of eggs laid as late as the end of July, of a protracted larval life with metamorphosis delayed till early in the following summer. In that case one would not expect to find many larvae in the water in July.

The smallest specimens collected were three males of $61.3,63.0$ and $65.7 \mathrm{~mm}$. in length, and two females of 66.5 and $67.6 \mathrm{~mm}$. in length. 
These five specimens which were taken in the water, and showed no more than a trace of the ventral black spotting of the adult, are remarkably small for the terrestrial form returning to the water. Pope (1924) after measuring 800 aquatic newts from twenty-seven different collections in various parts of the northeastern United States, found the minimum to be $71 \mathrm{~mm}$. Measurements of 284 specimens of the land form by the same author show the average to be $62.62 \mathrm{~mm}$., with a maximum of $100 \mathrm{~mm}$.

A total of 140 specimens was taken at Lake Nipigon, of which 85, or 60.7 per cent. were males. Most of these showed only a moderate or poor development of the tail fin and of the horny ridges on the hind legs. The cloacal villi were mostly well developed, as were also the facial pits. The testes showed great variation both in size and shape, and were relatively larger in animals of less than 87.0 and over $106 \mathrm{~mm}$.

Most of the specimens taken were of normal colouration, but a few were unusually dark.

Ambystoma.-Two species of this genus, $A$. jeffersonianum and A. maculatum were found.

Larvae were found in four localities differing considerably in their physiographic conditions, as follows: In the C.N.R. pools south of the tunnel near Macdiarmid; in some small permanent ponds close to the Toad pond near the mouth of the Pustagone river; in Newt lake and in Muskeg lake.

Salamanders were very generally absent from the islands of the lake, the single specimen of $A$. jeffersonianum referred to below being the only island record.

The spawn of Ambystoma, was not found, nor the spawning dates of either species noted. Records of stages of larval development at different dates and localities are as follows: On June 28, 1921 larvae ranging from 25 to $35 \mathrm{~mm}$. in length were taken in the C.N.R. pools south of the tunnel near Macdiarmid; on July 24, 1921 full grown larvae with gills absorbed to stubs were taken in Muskeg lake; on July 13, 1924 two specimens of less than $24 \mathrm{~mm}$., and with large gills were taken in a pond near the mouth of the Pustagone river; on July 21, 1924 larvae varying from 35 to $49 \mathrm{~mm}$., all with large gills were taken in Muskeg lake.

Ambystoma jeffersonianum (GREEN). JEFFERSON'S SALAMANDER.-This species was the commoner of the two, though not abundant. Ten adults were taken, eight at the southern extremity of Orient bay, one on top of a hill at Fairloch (at the fire rangers' lookout tower) and one on Shakespeare island.

The specimens from Orient bay were found under drift on the beach 
and around the shores of some ponds close to the beach, in July 1923 and June 1924. The Shakespeare island specimen was taken by Mr. J. L. Hart in June 1926. The specimen from the hill at Fairloch was taken by Mr. Dan Kerr in a small well on Aug. 7, 1921. The summit of this hill is exposed and dry, and sometimes becomes very hot under the mid-day sun. The slopes, though forested, are well drained and dry, especially on the east side which descends rather steeply with much exposed rock. The nearest body of water is Muskeg lake at the foot of the east slope where larvae were found.

All of the adults were young ones ranging in length from 73.5 to $110.5 \mathrm{~mm}$. Their colour was quite normal for young $A$. jeffersonianum.

Ambystoma maculatum (SHAw). SPOTTED SALAMANDER. -Three specimens were taken by Mr. Dan Kerr in the well on top of the hill at Fairloch, where the specimen of $A$. jeffersonianum referred to above, was found. The dates of capture were June 7,8 , and 30 , 1922. The specimens measured respectively 139, 92 and $130 \mathrm{~mm}$. and were quite normal in colouration.

Bufo americanus Holbrook. AMERICAN TOAD.-This species was common at Lake Nipigon. It was taken on the main land at Ombabika bay, Sturgeon river, Cedar creek, Macdiarmid, Pustagone river, Orient bay and McIntyre bay, and on four of the islands, Murchison, Shakespeare (Main island), Naonan, and on a small island close to St. Paul island.

It was scattered generally over a variety of country, -in light dry woods, about clearings, in river valleys, around sheltered bays and was seen once at First Station lake. It was common in the clearing about the village of Macdiarmid and on the Canadian National Railway right-of-way, breeding in the pools beside the track. It was found in considerable numbers near the mouth of the Pustagone river where the deep valley is wide and flat and clear of forest. At Ombabika bay it was taken in the clearing about the Revillon Frères buildings. Those taken at Sturgeon river were in the water at the edge of a clearing.

The toads in their wanderings showed the usual preference for moderately dry situations about clearings and in light, second growth woods. They were very scarce in the forest, a single specimen being taken in a forest of tall pines at McIntyre bay.

The specimens collected were exceedingly variable, especially in certain characters of the head. Five specimens examined by Dr. A. H. Wright, and shown by him to Dr. Remington Kellogg, were returned with the following comments: "A very variable lot, showing strong variation toward some three or four species or varieties". 
In one of these specimens there were no supratympanic nor postorbital crests and the tympanum was large. In another the temporal crests resembled those of $B$. hemiophrys, while the tympanum was small. In two others the supratympanic crests were absent, the postorbitals were in contact with the paratoids as in $B$. fowleri and the tympanum was large. Only one specimen was a normal B. americanus.

In general, the colour of the Nipigon toads was typical for northern $B$. americanus, with red as a strong note in a good many individuals. The males were usually more greenish or yellowish than the females and with less contrast in the dark mottling. Red was more frequently noted in the colour of the females, though occasional males showed a pronounced reddish hue, especially about the head and shoulders.

Evidence was obtained which indicated that the species bred in the quiet parts of rivers, in permanent ponds, in rocky shore pools maintained at level by the lake, in spring-fed pools, in temporary pools and in bays of the lake.

In 1924 spawning was observed at the Toad pond at the Pustagone river on June 5, and was evidently just commencing, as the strings of jelly were apparently fresh, having gathered no silt, and the eggs showed no signs of segmentation visible to the naked eye.

On June 14 numerous tadpoles of six to seven millimetres in length were found clinging to grasses close to the remains of the disintegrating spawn, much of which had failed to hatch.

By July 28 transformation was complete and no tadpoles were left in the water, but newly transformed toads were numerous on the shores of the pond, and in all those seen, except one, the tails were completely absorbed.

The period from the beginning of egg-laying till the beginning of metamorphosis in this pond was evidently about forty-six days. A development period of approximately the same length was noted in another pool observed concurrently.

Hyla crucifer WIED. SPRING PEEPER.-To judge by the evening and night choruses, $I I$. crucifer was by far the most abundant amphibian in the district, although, owing to its small size and shy and secretive habits, specimens were not often seen. Records were obtained from McIntyre bay, Orient bay, Pustagone river, Macdiarmid, Newt lake, Muskeg lake, First Station lake, Second Station lake, Crescent lake, and West bay. The species was in general plentiful where small bodies of impounded water occurred, but was rarely found about the shores of Lake Nipigon itself, which were probably too exposed to be attractive. It was apparently absent from the islands of the lake. 
The specimens collected ranged from 18 to $29.5 \mathrm{~mm}$. in length, and were quite typical in colouration.

The tadpoles were found only in ponds and small lakes, never in rivers nor in bays of Lake Nipigon. They were taken in Muskeg lake, Newt lake and Second Station lake, and from the Toad pond at the Pustagone river.

The date of the beginning of spawning was not determined. The earliest date on which tadpoles were found was June 14, 1924, when three very young specimens of less than $6 \mathrm{~mm}$. were secured along with other species at the Toad pond, Pustagone river. By June 21 they were plentiful and ranged from 7 to $14.5 \mathrm{~mm}$. By July 30 metamorphosis was well under way and many of the young frogs with large, or partly absorbed tails were hopping about the margins of the pond. The great range of size seen among the tadpoles on any given date would indicate a long spawning period for the species.

Rana cantabrigensis BAIRD. NORTHERN WOOD FROG.This frog was found to be very common both in wet woods and in more open country where water was available. It was taken on the main land at Ombabika bay, Onaman river, Sandy river, Crescent lake, Centre lake, First Station lake, Second Station lake, Macdiarmid, Pustagone river, Orient bay, Newt lake, McIntyre bay, Black Sturgeon bay, Gull bay, and West bay. It was taken also on Murchison and Shakespeare islands, and was plentiful at Shakespeare Island lake. Next to Hyla crucifer, it was the most abundant amphibian.

In general the coloration of the specimens collected was very similar to that of $R$. sylvatica, except that a few showed the white line down the middle of the back and along the upper surfaces of the hind limbs. In some this line was only faintly evident.

The largest specimen measured $51 \mathrm{~mm}$., and the average for thirtytwo adults was $42.17 \mathrm{~mm}$. The hind limbs showed great variation in length. Measurements of thirty-two adults give an average of 87.72 per cent. of the total length of head and body, with a maximum of 97.4 and a minimum of 77.46 per cent., a variation of almost 20 per cent. of the total length of the animal.

The eggs of this frog were not found, nor the date of egg laying determined. It is evidently the earliest spawner, as tadpoles half an inch in length were found on June 5, 1924 in a small pond near the Toad pond. By Aug. 2, transformation was in progress, but most of the young frogs still possessed their full tadpole tails and had not yet left the water.

In one of the C.N.R. pools at Macdiarmid, transformation was still 
further advanced on this date, and a number of the young frogs were about on the shore with their tails fully absorbed.

$R$. cantabrigensis was the only amphibian found commonly in the coniferous woods. Where the floor of the woods was wet and covered with sphagnum, these frogs were often seen about the small water holes numerous in such situations.

Rana clamitans LAtreille. GREEN FROG.-This species was fairly common, but less so than the wood frog. It was taken at Muskeg lake, and at another small lake farther inland at Fairloch, at Centre lake, Second Station lake, Macdiarmid, Pustagone river, Orient bay, Newt lake and South bay. The island records are from Shakespeare island and a small island near Gros Cap.

In coloration the green frogs of the Lake Nipigon region were sombre and dark. The bright green of head and shoulders, so characteristic of the species in more southern localities, was not seen in any of the specimens examined. A dull ground colour of medium to dark olive brown on the upper parts, with darker spots or blotches on the back and bands on the hind limbs was the usual condition. A few individuals were of a dull grayish green. Some of the specimens collected showed a tendency towards a still darker and unusual type of colouration, in the extreme of which, the upper parts were dark blackish brown with small irregular isolated spots of soiled straw-colour. A series of eleven specimens tending towards this type of colour and pattern showed a fairly well graded sequence of steps between it and the normal. This reversal of the normal colour plan in the adult was associated with a similar condition in the tadpole, in which the ground colour above was dark brown with small isolated spots of metallic green. The largest adult measured $84 \mathrm{~mm}$. in length.

The tadpoles were found in streams, ponds and small lakes. They were taken in a small creek at Macdiarmid, in a cool stream at South bay, in the Toad pond, in Newt lake, Centre lake and Second Station lake, and were seen in large numbers in a pond at the south end of Orient bay. They were plentiful in Shakespeare Island lake.

No definite information on breeding activities was obtained. A number of vociferous and very active males was seen in the Pustagone ponds on June 14. This was the first voice record. A female taken at these ponds on June 7 , contained a fair number of ripening eggs, and another specimen taken here on June 14, was distended with ripe eggs. A female taken at Orient bay on June 12, and one taken on Shakespeare island on July 8, were full of eggs.

By July 13 , most of the green frogs had dispersed from the Pustagone 
ponds and there was a new generation of very young tadpoles just recently hatched, which were possibly of this species.

To judge from the state of development of full grown tadpoles taken at various dates throughout the summer, transformation begins early in July and continues into August.

Rana pipiens Schreber. LEOPARD FROG.-This species, which is typically a lover of the open, cat-tail marshes, was seen less frequently than the green frog, but was not uncommon. It was taken on the main land at Ombabika bay, Onaman river, Muskeg lake, Cedar creek, Macdiarmid and at the Pustagone river. The island records are from Shakespeare and Naonan islands.

These frogs were found always in low lying, open country, never very far from water.

The colouration of the specimens seen was normal. The largest measured $86 \mathrm{~mm}$.

Neither the eggs nor tadpoles were found, and the only hint at breeding activities was at the Toad pond on June 14, when two male leopard frogs were found embracing female green frogs. Most of the females taken were small, and dissection of the few large ones does not throw enough light on the subject to be at all conclusive. The ovaries of a large female taken on June 14, contained only minute, white eggs. Another specimen taken on July 2 showed a similar condition. A specimen taken on July 24, was full of ripe eggs. Two newly transformed individuals were taken at Macdiarmid on Aug. 12, 1921.

Rana septentrionalis BAIRD. MINK FROG.-This interesting frog was not plentiful, and was the least common Rana in the district. Specimens were taken at Centre lake, Muskeg lake, First Station lake, Macdiarmid and Pustagone ponds.

It is a decidedly aquatic frog and was never seen at a greater distance from water than could be covered by a single leap. Its preference seemed to be for rivers and small lakes. In the latter it was found more especially about outlets or inlets where there is a gentle current. It was also found in quiet, bog-margined lakes without current. It was taken about water holes in the sphagnum-covered floor of wet, coniferous woods, and in the shallow pools beside the C.N.R. track at Macdiarmid.

The specimens collected ranged from 42 to $57 \mathrm{~mm}$. in length. The length of the hind leg to the ankle averaged 83.39 per cent. of the total leng th. In colouration the Nipigon specimens were quite similar to those seen in other parts of Ontario.

A croaking male was taken in First Station lake on July 5, 1924. A female taken in a water hole in the woods on June 4, 1922, contained 
ripening eggs. One taken at the C.N.R. pools, Macdiarmid, on June 11, 1921, was distended with ripe eggs. Another female taken at Centre lake on July 21, 1924, was without eggs.

\section{REPTILES}

Thamnophis s. sirtalis (LINN.). COMMON GARTER SNAKE. -This snake, the only species found, was not plentiful, only thirteen specimens having been secured. A few others were seen but escaped. It was taken at Macdiarmid, Cedar creek and Sandy river.

The specimens collected were quite typical. The dorsal scales were 19-17 in every case; the ventral plates ranged from 149 to 167 ; the supra labials were 7 , except in one specimen which had 8 on the left side; the infra labials were 10 in nine specimens, 9 in three, and 8 in one; the oculars in every case were $1-3$.

The specimens ranged in length from 202 to $968 \mathrm{~mm}$. In four, the tip of the tail was broken off. For the other nine the tail averaged 21.76 per cent. of the total length. The maximum was 25.55 and the minimum 20.52 per cent.

The colour and markings of these snakes was for the most part normal. The dorsal and lateral stripes were dull greenish yellow, as was also the belly. The lateral stripes were in most cases not well defined below, owing to the faintness of the dusky band on the first row of scales and edges of the ventral plates.

One specimen showed a melanistic tendency. The light lateral stripe was almost completely invaded by black, which also came well down on the margins of the ventral plates. The dorsal stripe was dusky and faded out completely at the base of the tail.

Another specimen showed much red in life, the lateral stripes being strongly reddish, especially on the anterior fifth of the body, the red extending onto the sides of the head. The ventral plates were finely mottled with red which was continuous across the first few plates behind the neck, and the last twenty-five or more in front of the vent.

Chrysemys marginata bellii (Gray). BELL'S TURTLE.-Only three specimens of this turtle were found; two at Blackwater river in June, 1921, by an Indian, and one at the south end of Orient bay on June 12, 1924, by L. L. Snyder.

The Orient bay specimen was a young one, the measurements taken with calipers were as follows: length of carapace $104 \mathrm{~mm}$., greatest width, $86 \mathrm{~mm}$., greatest depth of body, $27 \mathrm{~mm}$. The carapace was olive green and the plastron reddish, and all the markings were clear and brilliant. The Blackwater river specimens were large, their measur- 
ments were respectively: length of carapace, 176 and $200 \mathrm{~mm}$., greatest width, 132 and $144 \mathrm{~mm}$., greatest depth of body, 57 and $68 \mathrm{~mm}$. They were dark umber brown above and yellowish, suffused with red below, the markings for the most part rather dull and subdued. In all of these specimens the costal scutes were each crossed at the middle by a transverse, crescent-shaped, light bar. The dark patch on the plastron was also characteristic, sending out extensions along the sutures almost to the margin of the shell. In the young specimen all the spots on the limbs and the stripes on the head and neck were lemon yellow.

\section{Literature Cited}

Dymond, J. R. 1926. The fishes of Lake Nipigon. Univ. of Toronto Studies: Biol. Series, Pub. Ontario Fisheries Research Lab., No. 27. Gage, S. H. 1891. Life-history of the vermilion-spotted newt, Diemyctylus viridescens. Amer. Nat., 35: 1084-1110.

Pope, Philip H. 1924. The Life-history of the common water-newt (Notophthalmus viridescens) together with observations on the sense of smell. Annals Carnegie Museum, 15: 305-368.

Wilson, Alfred W. G. 1910. Geology of the Nipigon basin, Ontario. Memoir No. 1, Dept. Mines, Geol. Survey Br., Canada. 



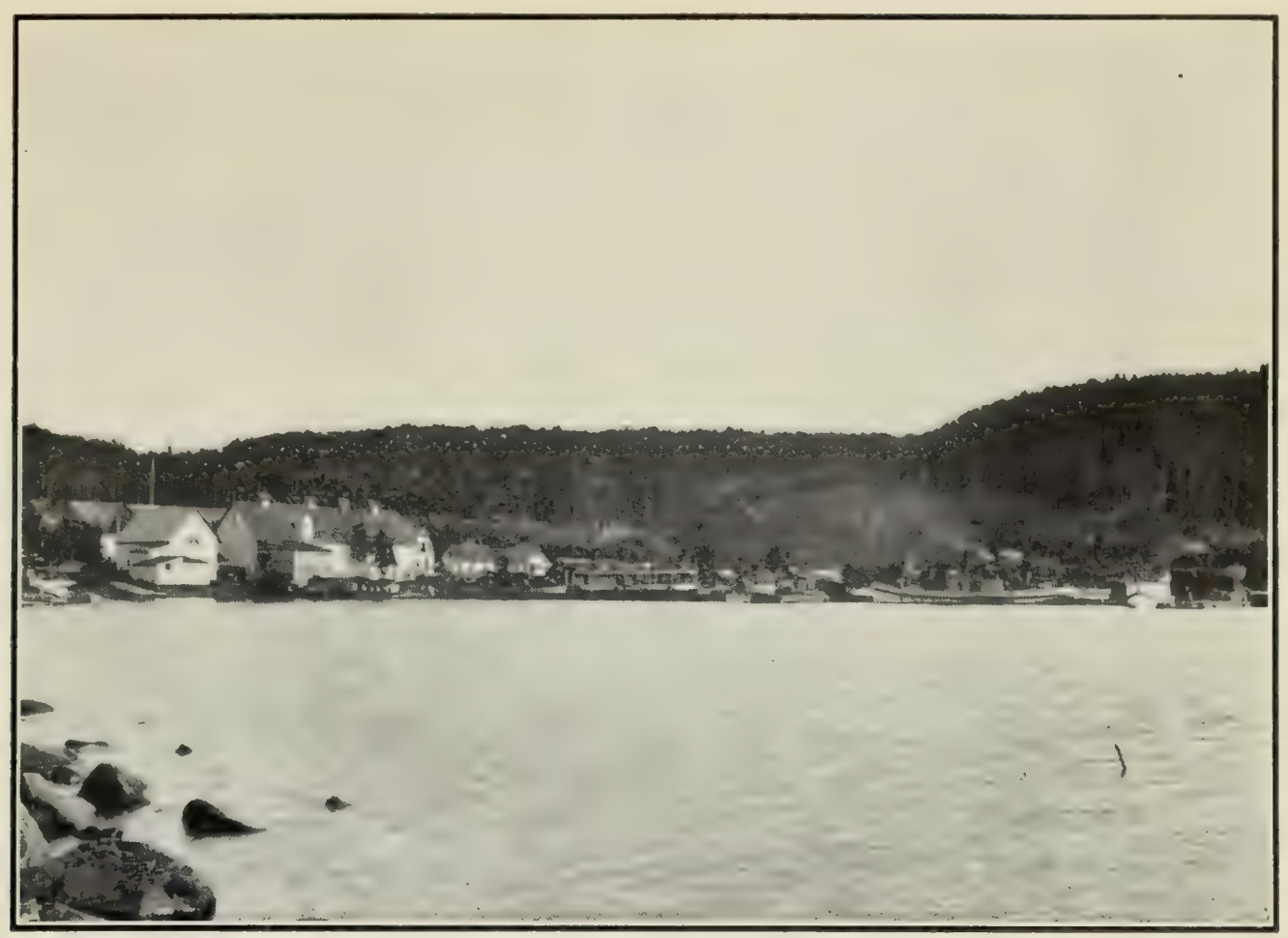

The Village of Macdiarmid.

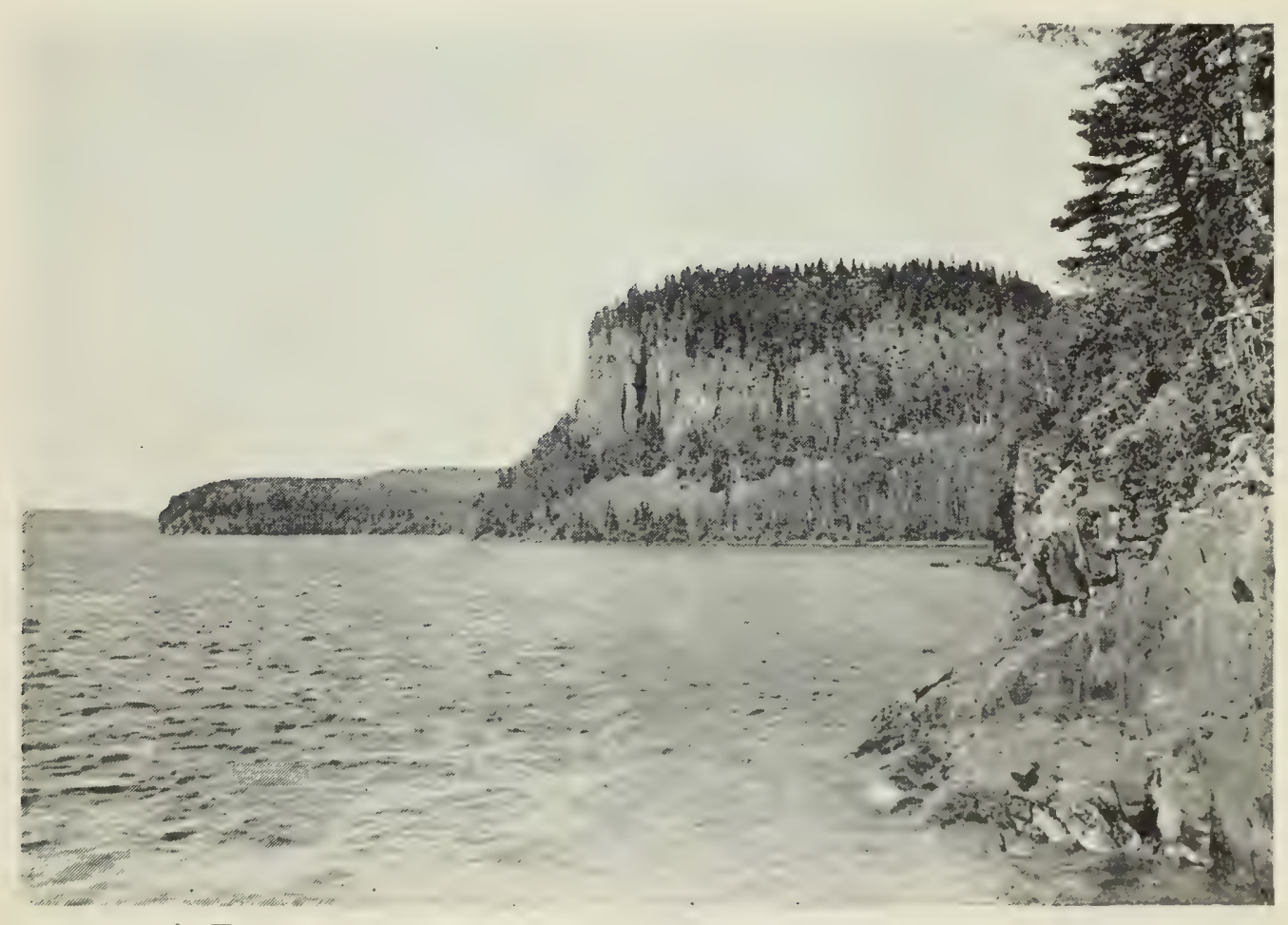

A Typical Stretch of Rocky Shore near Macdiarmid.

Dymond, Snyder and Logier on A Faunal Investigation of the Lake Nipigon Region. 


3). 262 9065 An $5+2^{3}$. 



(17) W.7.6.

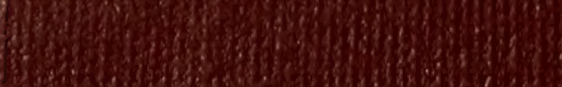
1060 